\title{
Do Concerns About Labor Market Competition Shape Attitudes Toward Immigration? New Evidence
}

\author{
Jens Hainmueller - Massachusetts Institute of Technology \\ Michael J. Hiscox - Harvard University \\ Yotam Margalit - Columbia University
}

September 2011

\begin{abstract}
Are concerns about labor market competition a powerful source of anti-immigrant sentiment? Several prominent studies have examined survey data on voters and concluded that fears about the negative effects of immigration on wages and employment play a major role generating anti-immigrant attitudes. We examine new data from a targeted survey of U.S. employees in 12 different industries. In contrast with previous studies, the findings indicate that fears about labor market competition do not appear to have substantial effects on attitudes toward immigration, and preferences with regard to immigration policy, among this large and diverse set of voters.
\end{abstract}

Jens Hainmueller, Department of Political Science, 77 Massachusetts Avenue, Cambridge, MA 02139. E-mail: jhainm@mit.edu. Michael J. Hiscox, Department of Government, 1737 Cambridge Street, Cambridge, MA 02138. E-mail: hiscox@fas.harvard.edu. Yotam Margalit, Department of Political Science, 420 W. 118th St. New York, NY 10027.ym2297@columbia.edu

We benefited from the comments of Adam Berinsky, Lisa Martin, Dennis Quinn, and participants at the Global Migration Conference at Tulane University, the Midwest Conference in Chicago, and the APSA conference in Seattle. Jeremy Ferwerda provided valuable research assistance. Funding for this research was generously provided by Harvard's Weatherhead Center for International Affairs. The usual disclaimer applies. 


\section{INTRODUCTION}

Are concerns about labor market competition a powerful source of anti-immigrant sentiment? Several prominent studies have recently examined survey data on voters and concluded that fears about the negative effects of immigration on wages and employment play a major role in generating anti-immigrant attitudes (Scheve and Slaughter, 2001; Mayda, 2006). The core claim made in these studies is that, to a large degree, voters form attitudes about immigration based upon calculations of material self interest and expectations about the labor market impacts of immigration.

The conclusions drawn in these previous studies are puzzling for two reasons. First, standard theoretical models generally predict that immigration has negligible or ambiguous effects on the wages and employment of most native workers. Second, these predictions from the models are generally confirmed by the bulk of the empirical research on the labor market impacts of past immigration flows into European and American labor markets in which the effects of such flows on income and employment of native workers are estimated to be quite small. In short, the best theory and evidence suggest that the job market effects of immigration should not be a concern for most voters, yet scholars examining survey data have concluded just the opposite. Resolving this contradiction is an important step towards improving our understanding of public opposition to immigration and support for anti-immigrant political movements and policy initiatives. If opposition to immigration is based upon self-interested economic calculations among voters, it might be addressed and mitigated by targeting forms of adjustment assistance and job creation programs that alleviate the negative effects of immigration for native workers anticipating the largest impacts. If opposition to immigration is motivated instead by more deep-seated cultural or ideological factors, these forms of economic assistance to native workers are less likely to be effective in addressing anti-immigration anxieties among voters.

An important constraint for studies examining voter attitudes towards immigration is that most opinion surveys are blunt instruments that fail to gather detailed data on the economic characteristics of the respondents and their views about specific types of immigrants. In particular, the most prominent (and frequently used) surveys ask few or no questions about 
respondents' employment experience, job training, and willingness and ability to find new jobs, and rarely identify the specific industries in which respondents are employed. In addition, these surveys ask respondents to describe their attitudes towards immigration in general without allowing for any differentiation in their views about varying types of immigrants (e.g., high-skilled versus low-skilled) that may be associated with different expectations about labor market impacts. As a consequence of these data constraints, previous studies that examine the importance of concerns about labor market competition in shaping anti-immigrant sentiments have been limited to the application of crude and indirect tests.

We address several important data constraints that have hampered previous scholarship in this area by conducting a large targeted survey of current employees in 12 industries in the United States. We examine potential relationships between the skill levels, industry locations, occupations, and mobility of these individual employees and their attitudes towards different types of immigrants. In contrast with previous studies, but consistent with predictions from standard theoretical models and research on the labor impacts of immigration, our tests indicate that fears about labor market competition do not have substantial effects on voter attitudes towards immigration.

Specifically, we find no evidence that individuals are systematically more likely to oppose the immigration of workers that possess skills similar to their own. Rather, workers of all types express greater support for inflows of high-skilled rather than low-skilled immigrants. Strikingly, this preference is evident among respondents in almost all segments of the labor force one compares: among high skilled and low skilled workers, for example, among production workers as well as managers, poor and rich individuals, high school drop-outs and individuals with graduate degrees, and workers located in all the industries we studied. While support for immigration varies across industries, this variation is explained by individual characteristics of respondents and not features of industries such as the degree to which industries rely upon immigrant labor in general, or upon high-skilled or low-skilled immigrants in particular. Industry-specific effects are not evident even when accounting for variation in skill specificity and job mobility among respondents.

We replicate all our main results based on stated attitudes towards immigration among 
survey respondents using a new, quasi-behavioral measure of the willingness of survey respondents to sign up to have an email message about their views on immigration policy sent on their behalf to their Member of Congress (which includes the respondent's name and city). The results from the analysis using this quasi-behavioral measure of attitudes confirm the main conclusions. Overall, the results indicate that material self-interest and fears about labor market competition do not appear to be powerful determinants of anti-immigrant sentiment. The results are more consistent with alternative accounts emphasizing non-economic concerns among voters associated with ethnocentrism or sociotropic considerations about the effects of immigration on the country as a whole (Bauer et al., 2000; Burns and Gimpel, 2000; Dustmann and Preston, 2007). These accounts connect to an extensive body of research indicating that material self-interest rarely plays a large role in shaping voters' opinions about major policy issues (Kinder and Sears, 1981; Sears et al., 1980).

\section{LABOR MARKET COMPETITION AND IMMIGRATION}

A large scholarly literature on attitudes toward immigration attributes anti-immigrant sentiments to a range of potential sources, including concerns about negative cultural, social, and economic effects among voters. Several prominent studies have recently emphasized considerations involving material self-interest, and in particular, people's concerns about immigrants threatening their earning capacities and employment opportunities (Scheve and Slaughter, 2001; Mayda, 2006). According to these accounts, individuals are substantially more opposed to immigration the more they perceive the incoming immigrants as harming their own earning prospects, and these material concerns play an important role in shaping general attitudes towards immigration policy. This claim, while ex ante plausible, raises the question of what underlies assessments of the labor market impacts of immigration.

\section{A. Theoretical Models}

Standard theoretical models of the labor market effects of immigration focus on the impact that immigration has on relative supplies of factors of production in the local economy. These models generally predict that immigration has negligible or ambiguous effects on the wages 
and employment of most native workers (Friedberg and Hunt, 1995; Gaston and Nelson, 2000).

Closed-economy models, which tend to predominate in work by labor economists, predict the largest impacts of immigration for native workers. In these models immigrants simply price themselves into employment by lowering the wages of native workers with similar skills $1^{1}$ The simplest of these types of models are sometimes referred to as "factor-proportions" (FP) analysis. In addition to the closed-economy restriction, these models also assume that immigrants are perfect substitutes for native workers in each skill category defined by education and experience (Borjas et al., 1996; Borjas, 1997, 1999, 2003, 2006). This model renders the distributive effects of immigrants in the starkest possible terms: immigration generates negative wage effects for similarly skilled natives, while natives with different skills benefit due to complementarities.

If we relax the assumption of perfect substitutability between immigrants and native workers, however, the predictions become more ambiguous, even in this closed-economy approach. Ottaviano and Peri (2006) develop a closed-economy model with labor - differentiated by education, age, and place of birth - as an input in a nested aggregate production function. Given a high degree of substitutability between immigrants and natives, immigrants mostly depress the demand for natives in any specific education-age group and augment the demand for natives in other skill groups; at low levels of substitutability, however, immigrants in a specific education-age category have a negligible effect on the demand for similarly skilled natives while still increasing the demand for natives with dissimilar skills. If the elasticity of substitution between immigrants and native workers is higher within some particular skill groups than others, the negative effects of immigration on wages of natives should be larger in those groups than among others (Orrenius and Zavodny, 2007)..$^{2}$

\footnotetext{
${ }^{1}$ The simplest models assume full employment and wage flexibility, so that the distributional effects are reflected in wages. Relaxing these assumptions allows that the effects of immigration can take the form of changes in local unemployment rates (Razin and Sadka, 1995, Angrist and Kugler, 2003). More complex models also allow for geographic differences within national labor markets so that the wage and employment effects of immigration may be concentrated in the short-term in "gateway communities" where immigrants tend to settle in large numbers and may be dissipated over time by internal migration of workers to other communities (Card and DiNardo, 2000, Card, 2001; Borjas, 1999).

2 Orrenius and Zavodny (2007) hypothesize that the elasticity of substitution may be greater among unskilled workers than among skilled workers, as the need for native language proficiency, institutional knowledge, and professional licenses may make it difficult for employers to substitute immigrants for native workers in higher skill categories. Peri and Sparber (2009) argue just the opposite: that is, since immigrants with low levels of
} 
In an open-economy Heckscher-Ohlin (HO) model, trade offsets the impact of immigration as the economy adjusts to any change in factor supplies by importing less of the goods that can now be produced locally at a lower cost (in line with the Rybcynski theorem). Wages will not change at all as long as the economy is not so large that a change in its output mix affects world prices - a result known as "factor price insensitivity" (Leamer and Levinsohn, 1995). This result holds for any number of factors $(n)$ used in the production of any number of traded commodities $(m)$, and allowing for production of any number of non-traded commodities (as long as $n \leq m)$. The fixity of the prices of traded goods pins down the prices of the factors and non-traded goods. The HO model's basic prediction is that immigration has negligible effects on wages of local workers $\mathrm{S}^{3}$

In the $\mathrm{HO}$ model, factors of production are assumed to be mobile between local industries. The open-economy "specific factors" (SF) model relaxes this assumption, allowing that some factors $(n>m)$ are employable only in specific industries (Jones, 1971). If all goods are traded, so that all prices are fixed in world markets, immigration lowers real wages for natives with similar skills, while raising real wages for natives in other skill categories. More specifically, inflows of low-skilled labor will lower real wages for low-skilled natives while raising real wages for high-skilled natives of all types - these latter gains are largest (smallest) for high-skilled workers in industries that use low-skilled labor more (less) intensively. Meanwhile, inflows of any type of high-skilled labor raise real wages of low-skilled natives while reducing real wages of all high-skilled natives - again, the latter losses are largest (smallest) for high-skilled workers in industries that use low-skilled labor more (less) intensively.

The SF model predicts that real wages of high (low)-skilled local workers will rise with inflows of low (high)-skilled immigrants. Local workers should fear labor competition effects

education tend to have less native language proficiency and institutional knowledge, they tend to specialize more in manual-intensive tasks than do natives; college-educated immigrants, on the other hand, are more likely to be proficient in the native language and thus similar to native workers. Evidence provided by Ottaviano and Peri (2011) suggests that the latter view is more accurate (see discussion below).

${ }^{3}$ There are two possible (seemingly exceptional) sets of conditions under which the HO model anticipates concerns among natives about labor market competition due to immigration. If the local economy is exceptionally large relative to the rest of the world, a change in its output mix brought about by inflows of immigrants could alter world prices of traded goods and thereby reduce the real wages of some native workers. Alternatively, factor price insensitivity could also be upset if we allow that the country specializes in producing a limited set of traded goods, and if immigration is large enough to induce a change in the set of goods produced locally, eliminating entire industries. 
from immigrants with similar skill levels, but they can anticipate positive effects when immigrants have different skill levels. This basic result approximates the simple prediction in the one-commodity, closed-economy FP model, which may now be regarded as a special case. In the multiple-commodity, open-economy SF model, the anticipated real wage effects vary in magnitude in a systematic fashion among the high-skilled depending upon factor-intensities in their industries. In particular, high-skilled natives should be more (less) concerned about inflows of high-skilled immigrants if they are in industries that use low-skilled labor more (less) intensively. Unlike the general insensitivity result in the HO model, however, these predicted distributional effects in the SF model are compromised by the inclusion of non-traded goods in the analysis. Once we allow for non-traded goods, predicted wage effects become ambiguous without further restrictions 4

Overall, the prevailing models generally predict that immigration has negligible or ambiguous effects on the wages and employment of most native workers. Large negative effects are anticipated only when one makes the most restrictive types of assumptions, ruling out entirely either traded or non-traded sectors, for example, or assuming high degrees of substitutability between immigrants and native workers. It is also important to note that virtually all of the models of immigration described above are "partial" equilibrium models in that they treat capital endowments as fixed. If we consider immigration as a component in the growth of the labor supply in a dynamic model of the economy, the impact on wages over the long term will depend on the rate of capital accumulation (Bhagwati, 2002). Investors can respond to any changes in the marginal productivity of capital caused by immigration flows. Ottaviano and Peri (2006) allow that capital stocks adjust to immigration to maintain a constant real return in their closed-economy model and show that this adjustment mitigates negative impacts of immigration on wages: 5

\footnotetext{
${ }^{4}$ If immigration can lead to a reduction in the price of non-traded goods (i.e., if it raises the output of such goods more rapidly than it raises aggregate demand for them), it is unclear whether native workers with skills similar to those of immigrants will be worse off in real terms (the outcome will depend in part on their consumption tastes).

${ }^{5}$ Also note that the standard models assume competitive markets. In alternative types of models allowing for economies of scale in production in the industries employing immigrants, a wide variety of outcomes become possible: immigration can generate higher real wages for native workers with similar skills, for instance (Brezis and Krugman, 1996).
} 


\section{B. Research on Labor Market Impacts and Voter Attitudes}

The standard theoretical models thus suggest, overall, that immigration has negligible or ambiguous implications on real wages for native workers. This overall impression is consistent with the findings reported in the bulk of the empirical research on the labor market impacts of immigration flows into European and American labor markets ${ }^{6}$ While some studies report evidence of adverse wage and employment effects for local workers as a consequence of immigration (Borjas et al., 1996; Borjas, 1999, 1997, 2003, 2005), many studies conclude that the impacts of immigration are fleetingly small (Card, 1990, 2001, 2005, 2007; Lewis, 2005), and some studies report positive long-term effects for local workers as a result of inflows of similarly skilled immigrants (Ottaviano and Peri, 2008). In a recent study Borjas (2003, p. 1335) summarizes the evidence observing that "the measured impact of immigration on the wages of native workers fluctuates widely from study to study (and sometimes even within the same study) but seems to cluster around zero."

Nevertheless, several studies in recent years have reported finding strong evidence that concerns about labor market competition are a major determinant of attitudes towards immigration among voters. Most prominently, perhaps, Scheve and Slaughter (2001) drew upon data from the National Election Studies (NES) surveys of U.S. voters in the 1990s and highlighted the positive correlation between the skill levels of respondents (as measured by years of education) and their support for immigration. Scheve and Slaughter interpreted this correlation as evidence that low skilled (less educated) local workers feared being forced to compete for jobs with low skilled immigrants, in line with predictions from a simple FP model. More recently Mayda (2006) examined cross-national survey data from the 1995 National Identity Module of the International Social Survey Programme (ISSP), as well as data collected between 1995 and 1997 by the World Value Survey (WVS). Mayda contends that the correlation between individual skill and support for immigration is related to the skill composition of the immigrants relative to the natives in the destination country; support for immigration among skilled workers is highest in those countries where natives are more skilled relative to immigrants and

\footnotetext{
${ }^{6}$ For general reviews see for example Friedberg and Hunt (1995); Bhagwati (2002); Card (2005); Borjas (1999); Longhi et al. (2005).
} 
thus stand to benefit more in material terms from immigration compared to skilled workers elsewhere. As in the Scheve and Slaughter analysis, the empirical relationship between the proxies of individual skill (measured by years of education or by categories of occupational skills) and support for immigration is seen as consistent with predictions from a simple FP model and interpreted as confirmation that natives' concerns about labor market competition play "a key and robust role in preference formation over immigration policy" (Mayda, 2006. p. 526).

These studies are impressive and novel attempts to use survey data to link theoretical claims about the labor market impact of immigration to people's views about immigration policy. Yet these studies are constrained in important ways by the data available from existing opinion surveys, which tend to be quite blunt instruments. The surveys used in these studies do not gather data on the economic characteristics of the respondents, and their views about specific types of immigrants, at a level of detail that is sufficient to reliably estimate the effects of concerns about labor market competition. For example, neither the NES (used by Scheve and Slaughter) nor the ISSP or WVS surveys (used by Mayda) asked detailed questions about respondents' employment experience, job training, their willingness and ability to find new jobs, or their industry location. The ISSP and WVS surveys actually provided no direct questions that would identify the specific industries in which respondents are employed. The NES surveys included only one open-ended question about the "type of business" in which employed respondents were working (answers to this question were then coded to identify industry locations approximately according to standard industrial classifications).

Even more constraining, perhaps, these existing surveys only ask respondents to describe their attitudes towards immigration in general without allowing for any differentiation in their views about different types of immigrants (e.g., high-skilled versus low-skilled) associated with expectations about labor market impacts.7 This is a major constraint, of course, because

[Scheve and Slaughter $(2001)$ used responses to the NES immigration question: "Do you think the number of immigrants from foreign countries who are permitted to come to the United States to live should be increased a little, increased a lot, decreased a little, decreased a lot, or left the same as it is now?" Mayda (2006) examined answers to the ISSP question: "Do you think the number of immigrants to (respondents country) nowadays should be: (a) reduced a lot, (b) reduced a little, (c) remain the same as it is, (d) increased a little, or (e) increased a lot." The WVS asked the following question: "How about people from other countries coming here to work. Which one of the following do you think the government should do (a) Let anyone come who wants 
the main prediction from the simplest version of the SF model (and the special-case factor proportions analysis) is that native workers should oppose inflows of immigrants with similar skills to their own but support inflows of immigrants with different skills. The interpretations made in previous studies using the existing survey data of voter attitudes thus rest on an assumption that survey respondents have low skilled immigrants in mind when answering questions about immigration in general. This assumption seems highly doubtful. Yet even permitting it, the data does not allow one to examine whether local workers have different views about low-skilled and high-skilled immigrants that are consistent with anticipated labormarket effects and individuals' calculations of their material self interest $8^{8}$ As a consequence of these data constraints, previous studies that examine the importance of concerns about labor market competition in shaping anti-immigrant sentiments among voters have so far applied only crude and indirect tests.

We address several of these constraints by conducting a large-scale targeted survey of current employees in 12 industries in the United States. The 12 industries were selected based on their variation along several important dimensions of exposure to globalization, including factor intensities and reliance upon immigrant workers. We sampled between 200 and about 560 currently employed native workers in each of these industries; sample sizes reflected the different aggregate sizes of the industries themselves. These large industry samples provide us with a unique opportunity to examine whether industry location shapes the formation of attitudes and policy preferences in ways anticipated by theory. The new survey also collected a great variety of detailed information about the employment experiences of respondents and their willingness and ability to find new jobs. These enable us to test the link between a broad range of potential labor market considerations and workers' attitudes towards immigration. Critically too, the survey asked respondents directly and separately for their views about different types of immigrants, differentiating clearly between high-skilled and low-skilled immigrants. This

to (b) Let people come as long as there are jobs available (c) Place strict limits on the number of foreigners who can come here (d) Prohibit people coming here from other countries? (e) Don't know."

${ }^{8}$ The only studies we are aware of which designed surveys that ask respondents specifically and separately about their attitudes towards high-skilled and low-skilled immigrants are those by Sniderman et al. (2004) and Hainmueller and Hiscox (2010). Both studies find that, contrary to previous claims that local workers are most concerned about immigrants who have similar skill levels to their own, instead both low skilled and highly skilled workers strongly prefer highly skilled immigrants over low skilled immigrants. 
distinction allows for much more direct tests of the theoretical predictions.

\section{DATA}

To test our hypotheses we administered a survey that measures attitudes towards different types of immigrants among a large sample of U.S. workers in selected industries. The survey was fielded with online survey firm YouGov/Polimetrix between September 2010 and February 2011. The survey design followed a customized two-stage sampling approach in which we first selected a set of 12 key industries, five in the manufacturing sector and the rest in services. Selection of industries was based on a number of criteria reflecting variability in their exposure to the impacts of globalization and size. We plotted all major industries along several relevant dimensions: dependence on immigrant labor, value-added per worker, offshoring activity, trade balance, and total employment. Based on these plots we identified the set of 12 industries that provided suitably broad variation along the dimensions of interest. The manufacturing industries selected for the survey include: food manufacturing, chemical manufacturing, computer and electronic product manufacturing, transportation equipment manufacturing, and fabricated metal product manufacturing. The selected service industries include: construction, telecommunications, educational services, ambulatory health care services, nursing and residential care, financial services, and internet and data processing services.

Figure 1 compares the 12 selected industries with the industries that we did not select with respect to their reliance on foreign-born workers ${ }^{9}$ The figure indicates that our selected industries are quite representative of the universe of industries with respect to dependence on immigrant labor. Our selection spans the range of industries from those with a relatively small share of immigrant workers, such as educational services and fabricated metal production ( $7 \%$ and $8 \%$, respectively), to those with much larger shares, including the computer electronics and food manufacturing industries $(21 \%, 27 \%$, respectively).

Figure 2 compares selected and non-selected industries according to value added per worker (a basic indicator of capital and skill intensity) and their score on Blinder's offshorability index 10 The size of the bubbles indicates the size of the industry as measured by total em-

\footnotetext{
${ }^{9}$ Industries are classified at the 3 digit NAICS level.

${ }^{10}$ The "offshorability index" is a subjective ranking that was constructed by Alan Blinder to measure the
} 
ployment. Our selection of industries for the survey includes a representative sample of the universe of industries. With respect to the skill intensity, our selected industries cover the whole range from highly skill-intensive industries (e.g., chemical manufacturing and financial services), industries characterized by mid-range skill intensity (e.g., transportation equipment and computer electronics manufacturing), as well as industries with low levels of value added per worker (e.g., construction and nursing). Similarly, the 12 selected industries cover the whole range of industries along the offshorability scale, from those with the most offshorable occupations (internet and data processing services) to the least offshorable (nursing and education). Note that the omitted industries which are more extreme on these dimensions are very small in terms of their overall employment, such as the oil and gas extraction industry. We chose not to include those industries in the study because of the inherent difficulty in sampling them properly.

Based on those considerations, we subsequently recruited from each of the target industries a sizeable sample of native respondents that are currently employed (i.e., we excluded both foreign born workers and unemployed workers from our sample). The sample sizes we obtained were roughly proportional to the size of each industry. Table 1 provides the descriptive statistics 11

The survey includes a variety of questions that measure workers' preferences over immigration policy. For the main part of the analysis we focus on a survey experiment that measures the preferences of workers with respect to potential immigrants that differ on two key dimensions: they are described as being either highly skilled or low skilled and as being either familiar or not familiar with American values and traditions. Respondents were thus asked about their support for one of four possible types of potential immigrants ${ }^{12}$ This differentiation allows for potential offshorability of occupations. The index measures the offshorability of a job on a 100 point scale, where 100 equals most offshorable. Notice that the ranking is meant to be ordinal not cardinal (see Blinder (2009) for details). We summarize the offshorability of each industry based on a weighted average of the offshorability scores of the five most important occupations in each industry (weighted by their relative shares on total industry employment).

${ }^{11}$ To address potential non-response bias, here and in all other analysis the results are weighted by poststratification weights which ensure that the industry samples in our survey match the population level characteristics in each industry as measured by the 2009 March Supplement of the Current Population survey. The weighting adjustment includes brackets for the age, race, and education distributions of the workers employed in each industry.

${ }^{12}$ The four types are: (i) highly skilled immigrants that are well familiar with U.S. customs and traditions; 
a nuanced examination of the role of concerns about labor market competition in the broad - cultural as well as economic - context in which the immigration issue is typically debated. The question we use to gauge people's attitudes on the different types of immigration reads as follows:

Immigrants to the U.S. differ in terms of their professional skill levels as well as their degree of familiarity with American values and tradition. Consider the group of [highlyskilled/low skilled] immigrants that are [well familiar / not familiar] with American values and traditions. Do you think the U.S. should allow more or less of these immigrants to come and live here?

The answer categories included a five point scale that ranged from "Allow a lot more of these immigrants" to "Allow a lot less of these immigrants." Both the skill frame (i.e. highlyskilled vs. low skilled) and the values frame (i.e. well familiar vs. not familiar with U.S. values and tradition) were randomly assigned in their order across respondents, with each one being asked about all four categories of immigrants in random order.

Since our primary concern here is with assessing the differential effect of skill, we pool attitudes over both the cultural conditions for our empirical tests. We code a binary indicator ProImmigration that takes the value one for respondents that support allowing a lot or somewhat more immigrants, and zero otherwise. In addition to the test using the variables described above, we also replicated the subsequent analyses using a variety of other immigration questions and answer codings; the results are substantively identical to the ones presented below 13

\section{Results}

\section{A. Skill Levels of Respondents}

Recall the main prediction from the (restricted) SF model and the simpler FP analysis is that, if labor market concerns are an influential source of attitudes, voters should oppose immigrants

(ii) highly skilled immigrants that are not familiar with U.S. customs and traditions; (iii) low skilled immigrants that are well familiar with U.S. customs and traditions; (iv) low skilled immigrants that are not familiar with U.S. customs and traditions.

${ }^{13}$ In particular, the results are substantively similar if we use ordered probit regressions on the 5 point answer scale or alternative questions such as "Overall, do you think the number of immigrants allowed into the United States should be increased, decreased, or kept at the current level?", with responses again ranging on a five-point scale. 
with similar skills to their own but support immigrants with different skills. We begin the analysis by testing this prediction that low- (high-) skilled natives are more concerned about the inflow of low- (high-) skilled migrants than they are about the entry of high-(low-) skilled migrants.

We estimate a probit model in which the dependent variable is the level of support for an increase in immigration (ProImmigration) of either highly-skilled or low-skilled immigrants. The estimation includes a full set of baseline covariates, including the native worker's highest level of educational attainment $\sqrt{14}$ Of key interest in this test is whether an increase in native's skill is associated with less support for the entry of highly skilled immigrants. In the top row of Table 2 we report the effect of education on support for increasing immigration estimated from models that are fitted to the full sample of workers in all industries; column (1) reports the effect of education on preferences with respect to the entry of highly skilled immigrants and column (2) with respect to low skilled immigrants. As the reported coefficients indicate, the marginal effect of education is positive and larger in the case of attitudes on high skilled immigrants than on lower skilled immigrants. The difference in the estimated effects is highly significant $(\mathrm{p} .<.01) 15$

To provide a more intuitive sense of the magnitudes associated with this estimation, Figure 3 presents graphically the predicted level of support for increased immigration as a function of each educational level, using the regression estimates from the first row in Table 2. For each educational level we report separately the predicted rate of support for the entry of high skilled immigrants (in black) and low skilled immigration (in lighter gray) while fixing the other covariates at the values that describe the median worker. The vertical lines denote the 95\% confidence interval surrounding the point estimates. Figure 3 highlights several notable patterns. First, in line with previous studies, we find that anti-immigrant sentiments run high among U.S. workers. On average, only about $21 \%$ of workers are in favor of increasing

\footnotetext{
${ }^{14}$ The covariates include respondents' education, gender, age, race, marital status, income, union membership, region, and an indicator variable denoting whether the respondent was asked about immigrants with a high or low degree of familiarity with local culture and tradition.

${ }^{15}$ To test for the difference in the effects, we pool the observations across treatments and estimate a single model in which we interact native's education and the skill-level of the immigrants in question. The coefficient of the interaction term is positive and precisely estimated. See Appendix Table A.1 for results.
} 
immigration beyond its current levels. Among native workers with only high school education, support for expanded immigration of low skilled workers drops as low as 10\%, rising up to a maximum of $53 \%$ in the case of natives with post-graduate education ${ }^{16}$ A second pattern that the graph reveals is the one noted above, namely a strong positive relationship between the skill level of the natives (as measured by educational attainment) and the corresponding level of support for immigration. The differences across the skill groups are statistically significant as well as sizable in a substantive sense: mean support for increased immigration is $10 \%$ [ $8 \%$ to $13 \%$ ] among natives with less than high school education and rising to $35 \%$ [32\% to 39\%] among natives with graduate education. Third, the graph shows that workers at all levels of skill are more supportive of high skilled immigration than of low skilled immigration (on average, only $15 \%$ [ $14 \%$ to $17 \%$ ] of native workers are in favor of increasing low skilled immigration while $27 \%$ [25\% to $28 \%$ ] are in favor of increasing highly skilled immigration). This pattern is clearly at odds with the basic prediction derived from the FP and SF models, which suggests that highly skilled natives should oppose inflows of highly skilled immigrants but be less concerned about the inflow of low-skilled immigrants.

Finally, the analysis reveals that the "premium" that natives attach to the skill level of the immigrants (i.e. the gap in support for high versus low skilled immigration) is consistently increasing as a function of the natives' own level of skill in both relative and absolute terms. Among workers with less than high school education $9 \%$ are in favor of low skilled, and $16 \%$ are in favor of highly skilled immigration. Among workers with graduate education, $32 \%$ are in favor of low skilled immigration, while $53 \%$ are in favor of highly skilled immigration.

\section{B. Test for Industry Specific Effects}

By imposing the constraint that anticipated effects are constant across industries, we are not allowing a complete test of the SF model. Recall that in the multiple-commodity, open-economy SF model (in contrast to the simple FP analysis), the anticipated effects of immigration may vary in magnitude among high-skilled natives depending upon factor-intensities in their industries. In particular, the model anticipates that high-skilled natives will be more (less) concerned

\footnotetext{
${ }^{16}$ Note that this is the only case in which the probability of support is higher than fifty percent.
} 
about inflows of high-skilled immigrants if they are in industries that use low-skilled labor more (less) intensively. In essence, if workers have skills that are specific to particular industries, their policy preferences may vary significantly as a function of how immigration affects the demand for labor within their industry. To test this proposition, we return to the benchmark model but this time estimate the effect of higher educational qualifications separately for each industry.

The results for this estimation are reported in Table2, Each of the cell entries corresponding to an industry denotes the estimated effect of education on the probability of supporting increased immigration. To simplify the comparison of the magnitude of the education effects across industries, Figure 4 graphs the simulated marginal effects of education (a one unit increase of going from less than college education to a college degree) holding all the other covariates at the industry medians ${ }^{17}$ The industries along the horizontal axis are sorted by a measure of skill intensity (value added per worker), ranging from highly skill-intensive industries (chemical manufacturing and financial services) to those with the low levels of value added per worker (construction and nursing). The figure indicates that variation in support for immigration among high-versus-low skilled workers has little to do with industry factor intensity; no clear pattern differentiates the effect of natives' skills on support for immigration in the industries along the scale.

The fact that all but one of the point estimates are located on the positive range of the horizontal axis indicates that higher education among natives is consistently associated with increased support for immigration, regardless of the industry one is employed in. And as with the previous analysis, we again observe that higher education is associated with more support for high as opposed to low skilled-immigration, an empirical relationship that holds true in a large majority of the industries.18 There is no support here for the SF model (with no nontraded goods) that suggests variation in the impacts of immigration on high-skilled workers employed in different industries.

\footnotetext{
${ }^{17}$ The results are statistically and substantively similar if we estimate the predicted probabilities for the median respondents in the sample rather than in the industry.

${ }^{18}$ In those industries where the marginal effect of education is associated with a larger positive coefficient for low-skilled immigration, the differences between coefficients for low and high-skilled immigration are statistically indistinguishable from zero.
} 
To allow for other potential differences in workers' preferences across the industries, perhaps related to ad hoc labor market concerns that are not incorporated in the standard general equilibrium models, we estimate a model in which we use the same covariates of the benchmark model but also include indicator variables for each of the industries. With this model we can compare the mean differences in support for immigration across the different industries (using the nursing industry as our baseline category). Table 3 reports the estimates from this regression and Figure 5 plots the estimates for ease of interpretation 19 We report in black the predicted rate of support for the entry of high-skilled immigrants and in lighter gray the support for low-skilled immigration. The plot presents the predicted support level of the median worker in each industry as a function of the industry's share of foreign born workers, ranging from the industry most reliant on immigrant labor (food manufacturing) to the least reliant industry (educational services). It is possible that native workers in industries in which there is a high share of immigrants feel more concerned about competition for jobs as a result of immigration. The opposite is also feasible: perhaps workers in industries that already rely upon immigrant workers expect positive impacts from increased immigration as a result of (industry-specific) complementarities between themselves and immigrant workers. The graph indicates that variation in support for immigration actually has little to do with share of foreign-born workers in the industry: no clear pattern differentiates the level of support for immigration in the industries along the scale and in fact, support for both types of immigration is almost identical in the industries at the opposite extremes of the scale.

Figure 6 shows that support for immigration, and the general preference for highly-skilled versus low-skilled immigration, is unrelated to the relative skill ratio of the industry. The skill ratio is measured as the share of highly-skilled natives relative to the share of highly-skilled immigrants employed in the industry.20 In fact, the graph indicates that there is hardly any correlation between the premium assigned to migrants' skill level and the skill mix of the

\footnotetext{
${ }^{19}$ Note that unlike the results reported in Table 2, in this table the cell entries report the coefficients of each industry dummy obtained from estimating a single regression (not a set of separate regressions for each industry).

${ }^{20}$ Let NR be the share of native workers that are highly skilled and MR be the share of foreign born workers that are highly skilled. The relative skill ratio is then simply NR/MR. We defined highly skilled as workers that have a college degree or higher educational attainment. We compute the relative skill ratios from the March supplement of the Current Population Survey.
} 
workers employed in the industry. This pattern cannot be reconciled with the conjecture that self-interested concerns about the wage or employment effects of immigrants are an important source of attitudes towards immigration.

The empirical patterns reported above remain largely unchanged when we separately examine the preferences of high and low-skilled natives. Using the four models reported in columns (3) - (6) in Table 3, we plot the cross-industry differences in predicted support for immigration separately by native's own skill endowments. Figures $7 \mathrm{a}$ and $7 \mathrm{~b}$ present the results, with the top panel comparing the views of the high-skilled native worker and the lower panel presenting the predicted preferences among low-skilled natives. In this analysis industries are sorted along the horizontal axis by their score on a measure of inter-industry mobility, whereby higher scores denote a lower degree of confidence among workers of being able to find a comparable job in another industry if they were to look for one ${ }^{21}$ If labor market concerns underlie attitudes on immigration, we may expect support for immigration would be greater in those industries in which workers perceive their own labor market prospects to be less dependent on the employment opportunities within the industry.

The findings, however, offer very little to suggest that mobility prospects are an important factor explaining cross-industry differences in workers' preferences: Variation in attitudes on immigration across industries does not correspond in any discernable way with the mobility prospects of workers in different industries (As Figure A.1 in the appendix demonstrates, a similar pattern arises also when we use an alternative measure capturing mobility prospects within their industry) ${ }^{22}$ Furthermore, we find that this pattern does not alter when examining the policy preferences of high and low skilled natives separately. In both cases, support for allowing high skilled immigration is consistently greater than for allowing the entry of low skilled migrants. Again, this pattern does not vary with respect to the industry's mobility

\footnotetext{
${ }^{21}$ The measure is based on respondents' response to the question: "How easy or difficult would it be for you to find a job in another industry that pays as well or better than the job you currently have?". Responses ranged on a five-point scale from (1) "very easy" to (5) "very difficult". A separate measure of mobility was calculated for highly skilled and low-skilled native workers in each industry. For this reason, the industries are sorted differently along the horizontal axis in the two graphs.

${ }^{22}$ This measure is based on respondents' answer to a question: "If for some reason you were to lose your job, how easy or difficult would it be for you to find another job in the same industry that pays as well or better than the job you currently have?", with responses again ranging on a five-point scale.
} 
measure; when one examines workers' support for a specific type of labor inflow - of highly skilled or of low skilled immigrants - the level of support is almost flat across industries ${ }^{23}$

We have replicated these tests using a variety of other variables by which we order the industries, such as by the percent of highly skilled immigrant workers, the percent of low skilled immigrant workers, or by redefining the skill ratios with various different educationlevel cut-points; without exception, the substantive results remain unchanged.

\section{An Alternative (Quasi-Behavioral) Dependent Variable}

The findings presented above provide strong evidence that the expressed views of workers towards immigration do not correspond with extant arguments about the importance of concerns about labor market competition in shaping attitudes. Regardless of whether one analyzes the preferences of all workers as a whole, subsets the analysis by the skill endowments of the native workers, focuses on attitudes towards low skilled or highly skilled immigrants, allows for differences in factor intensities (and other characteristics) among industries, no matter what metric one uses, none of the analyses lends support to the notion that concerns about labor market competition systematically and substantially affects attitudes toward immigration.

To what extent might this (null)finding reflect the fact that workers are answering a hypothetical question about immigration in a survey context that poses no costs or consequences? Perhaps when people's preferences necessitate the taking of some form of costly (and potentially consequential) action, be it participation in a demonstration, casting a vote for a certain candidate in an election, or contacting one's elected officials to lobby for a certain policy, perhaps then people's views better correspond with the predictions of the labor market competition model?

In considering this possibility, one might first note that the previous studies which have purported to find evidence of the role of concerns about labor market competition have themselves relied on exactly this same type of "costless" measure - namely, people's responses to a hypothetical question about their views in a survey context. Nonetheless, in order to test this proposition seriously, we also carried out an experiment which was embedded into our

\footnotetext{
${ }^{23}$ Workers in the internet and data processing industry appear to be quite an outlier in this regard.
} 
cross-industry study. The experiment was designed as follows: when nearing the end of the survey, respondents were asked whether they would like to communicate their position on immigration in an email to their Member of Congress that will be sent via the online platform of the survey company. If respondents answered in the affirmative, they then had the option of choosing whether they wished to express support or opposition to a more restrictive immigration policy. Yet not all respondents were asked the same immigration question. Instead, respondents were randomly assigned to receive one of two different versions of the question: some were asked whether they wished to send an email expressing their views on the entry of low skilled immigration while others were asked the same question only about high-skilled immigration. The exact wording of the experiment read as follows:

Would you like us to send an email message to Members of Congress indicating either your support or opposition to pending immigration laws that propose to decrease the number of $\{$ highly skilled/ low skilled $\}$ immigrants allowed into the United States? The email will contain your name, city, and opinion on the issue.

Overall, 34\% of respondents requested to use this option to send the email to their elected official. Among those that requested to do so, $68 \%$ asked to express their support for placing restrictions on immigration and $32 \%$ to express their opposition.

Utilizing the responses to this alternative measure of preferences, we replicate the analysis presented in Figure 2, this time using as the dependent variable the specific version of the letter which respondents' chose to send their Member of Congress (note however that the dependent variable is support for placing more restrictions on immigration, i.e., the opposite of the measure used in Figure 2).

As before, the figure reveals a negative relationship between educational attainment and opposition to immigration, a relationship that is similarly pronounced in regards to the entry of both low and high-skilled migrants. This indicates that the patterns presented herein using the hypothetical survey questions are substantively unchanged when using a more "behavioral" measure of workers' immigration attitudes. We also replicate all the other analyses using this alternative behavioral measure and again find that the results remain substantively unchanged. (See appendix Figures A.2, A.3, and A.4. 


\section{Discussion}

Taken together, our results suggest that fears about labor market competition do not have substantial effects on voter attitudes towards immigration. We examine potential relationships between the skill levels, industry locations, occupations, and mobility of native workers and their attitudes towards different types of immigrants. We find no evidence that individuals are systematically more likely to oppose the immigration of workers that have skills similar to their own. Rather, workers of all types express greater support for inflows of high-skilled rather than low-skilled immigrants. This preference is almost identical among high-skilled and low-skilled respondents, among production workers as well as managers, poor and rich individuals, high school drop-outs and individuals with graduate degrees, and workers located in all the industries we studied. This pattern is at odds with the basic prediction derived from the FP and (restricted) SF models which anticipate that highly skilled natives should oppose inflows of highly skilled immigrants but be less concerned about the inflow of low-skilled im-

migrants, if labor-market concerns are an important determinant of attitudes. Other concerns and calculations, perhaps related to the fiscal effects of high- vs. low-skilled immigrants, or social and cultural impacts, appear to be dominant.

While we do find that support for immigration varies across industries, this variation is almost entirely explained by individual characteristics of respondents and not by features of industries such as the degree to which the industries rely upon immigrant labor in general, or on high-skilled versus low-skilled immigrants. Industry-specific effects are not evident even when accounting for variation in skill specificity and job mobility among respondents. We replicate all our main results based on stated attitudes towards immigration among survey respondents using a quasi-behavioral measure of the willingness of survey respondents to sign up to have their views conveyed to their Member of Congress via an email message.

Could the finding that workers at all levels of skill are more supportive of high-skilled than of low skilled immigration be interpreted in some alternative way that is more consistent with labor-market concerns shaping attitudes toward immigration? Perhaps one could argue that the elasticity of substitution between immigrants and natives is quite low among highly skilled categories of workers but high among unskilled workers. If substitutability between high- 
skilled immigrants and natives is low enough, complementarities in production may imply that inflows of highly skilled foreign workers would generate a positive effect on the wages of highly skilled natives. Orrenius and Zavodny (2007) have suggested that the substitution between immigrant and native workers may be easier in low skilled categories than among highly skilled workers where proficiency in the native language is more likely to be required for satisfactory performance on the job. But Ottaviano and Peri (2011) provide estimates of the elasticities of substitution between natives and immigrants of similar education and experience levels and find just the opposite: lower elasticities of substitution among less skilled categories of workers. They conclude that imperfect substitutability between immigrants and natives derives from somewhat different skills among these groups leading to different kinds of occupational specialization, especially among less skilled workers. Precisely because low skilled immigrants tend to have less native language proficiency, they are more likely to differentiate themselves from natives in the same skill category by specializing more in manual-intensive tasks. In contrast, well-educated immigrants are more likely to be proficient in the native language and thus can serve more easily as a substitute for native counterparts. If anything, then, negative wage effects from competition with immigrants should be more of a concern among high skilled natives contemplating inflows of highly skilled immigrants than among the low skilled natives contemplating low skilled immigration - the opposite of the pattern we observe in our data.

Finally, it is important to note that in this analysis we have focused on the distinction between high-skilled and low-skilled immigrants as the key characteristic shaping divergent expectations about the labor market effects of immigration. In doing so we are keeping the analysis closely in line with the standard theoretical treatments (in the FP, HO, and SF models), and with the previous studies of attitudes towards immigration that focus on voters' concerns about labor market competition (Scheve and Slaughter, 2001; Mayda, 2006). But why not make more fine-grained distinctions between various specific types of skills potential immigrants could possess? Why not ask respondents for their views about whether the U.S. should allow more or less doctors to come and live here, or lawyers, or aeronautical engineers, or plumbers, welders, electricians, teachers, and so on? Or why not ask respondents about 
allowing in more or less immigrants who have exactly the same professional skills as their own? One could ask professional mathematicians, for example, whether they would like more or less foreign mathematicians be allowed to enter (Borjas and Doran, 2011). Surely, if questions were framed in such ways, respondents would be better able to identify a specific set of potential immigrants with whom they could expect to compete for jobs and who they may thus prefer not be allowed into the country.

If the question is whether or not individuals anticipate labor market competition from some - that is, any - specific sets of potential immigrants, and are thus inclined to oppose entry for those specific immigrants, such fine-grained survey questions could be quite useful. Indeed, recent evidence indicates that when asked specifically about the expansion of H1-B visas temporary entry permits for predominantly high-technology workers - native workers in the high technology sector are more likely to be opposed than other natives employed in other sectors (Malhotra et al., 2011).

But the core question with which we are concerned here is quite different. What we are interested in is the question addressed in previous scholarship: whether material concerns about labor market competition play an important role in shaping voters' attitudes towards immigration in general - that is, at the level at which immigration policy is publicly discussed and debated. Policy debates frame the immigration issue in very general terms: whether the country should allow more immigration or less, in total, or whether to try to attract highly skilled immigrants and limit inflows of low skilled (and often also undocumented) immigrants. Rarely, if ever, do policymakers identify specific types of potential immigrants according to their particular professional skills (doctors, lawyers, plumbers, etc.) and debate how many of each category should be allowed to come and live in the country. The simple framing of the immigration issue in public debates reflects the blunt structure of immigration law and policy. In most countries immigration laws draw only broad distinctions between different types of potential immigrants ${ }^{24}$ U.S. immigration law, for example, defines categories of immigrants (and temporary foreign visitors) according to the general purpose for their entry

\footnotetext{
${ }^{24}$ Canada and Australia are perhaps the main recent exceptions, both having adopted elaborate points-based systems for selecting immigrant workers in specific occupational categories based upon calculations about local labor market supply and demand and the qualifications and professional experience of the individual applicants.
} 
and the associated eligibility requirements. For foreigners seeking entry to work in the U.S., the existing tracks of entry for permanent residence distinguish "skilled workers" and "priority workers" (including executives, outstanding researchers, and those with extraordinary skills) and eligibility for consideration in these tracks requires proof of educational degrees, work experience, and professional achievements; applicants who do not fit in these categories can apply as "unskilled workers." 25 In a review of all thirty-two bills voted for in Congress which dealt with immigration in the period from 2000-2010, we found that not a single one of them discussed immigration with reference to any specific category of occupation or industry 26 The political discussions are focused instead on the broader distinction between highly-skilled immigrants and others. This is the politically relevant distinction that we focus on here in our study.

Our findings are consistent with expectations based upon standard theoretical models under the least restrictive assumptions, and with research on the labor impacts of immigration, though they stand in marked contrast to previous studies of voter attitudes toward immigration that were constrained to the study of samples with very limited employment information about the workers. Overall, our results indicate that material self-interest, manifest here among voters as a calculation about the personal labor market effects of immigration, do not appear to be powerful determinants of anti-immigrant sentiment. These results are more consistent with alternative accounts of opposition to immigration that emphasize non-economic considerations and concerns about the effects of immigration on the country as a whole. They may be added to the impressive body of research that suggests that material self-interest rarely plays a large role in determining voters' attitudes towards major policy issues.

\footnotetext{
${ }^{25}$ For foreigners seeking entry to work in the U.S. on a temporary basis, the existing visa categories distinguish those with "extraordinary ability" (the O-1 visa) or who are otherwise "highly skilled" (H-1B) from agricultural workers $(\mathrm{H}-2 \mathrm{~A})$, other seasonal workers $(\mathrm{H}-2 \mathrm{~B})$, and trainees (H-3). The only category of entry for work that is related to skills for a specific industry or occupation is the temporary work visa for nurses (H-1C).

${ }^{26}$ See Challen (2011) for a comprehensive review of U.S. immigration law since 1965 that describes all workrelated tracks of entry for permanent and temporary residence along with eligibility requirements and, where applicable, annual quota allotments and actual inflows.
} 


\section{REFERENCES}

Angrist, J. and Kugler, A. (2003), 'Protective or counter-productive? labour market institutions and the effect of immigration on eu natives', Economic Journal 113(488), 302-331.

Bauer, T. K., Lofstrom, M. and Zimmerman, K. F. (2000), 'Immigration policy, assimilation of immigrants, and natives sentiments towards immigrants: Evidence from 12 oecd-countries', IZA Discussion Paper No. 187.

Bhagwati, J. (2002), The Wind of the Hundred Days: How Washington Mismanaged Globalization, MIT Press.

Blinder, A. (2009), 'How many US jobs might be offshorable?', World Economics 10(2), 41-78.

Borjas, G. (1997), 'How Much Do Immigration and Trade Affect Labor Market Outcomes?', Brookings Papers on Economic Activity .

Borjas, G. (1999), Heavens Door, Princeton: Princeton University Press.

Borjas, G. (2003), 'The Labor Demand Curve Is Downward Sloping: Reexamining The Impact Of Immigration On The Labor Market', The Quarterly Journal of Economics 118(4), 13351374 .

Borjas, G. (2005), Native Internal Migration and the Labor Market Impact of Immigration, National Bureau of Economic Research Cambridge, Mass., USA.

Borjas, G. (2006), 'Native internal migration and the labor market impact of immigration', Journal of Human Resources XLI(2), 221-258.

Borjas, G. and Doran, K. B. (2011), 'The collapse of the soviet union and the productivity of american mathematicians', Working Paper Harvard University .

Borjas, G., Freeman, R. and Katz, L. (1996), 'Searching for the Effect of Immigration on the Labor Market', The American Economic Review 86(2), 246-251.

Brezis, E. and Krugman, P. (1996), 'Immigration, Investment, and Real Wages', Journal of Population Economics 9(1), 83-93.

Burns, P. and Gimpel, J. (2000), 'Economic insecurity, prejudicial stereotypes, and public opinion on immigration policy', Political Science Quarterly 115(3), 201-225.

Card, D. (1990), 'The Impact of the Mariel Boatlift on the Miami Labor Market', Industrial and Labor Relations Review 43(2), 245-257.

Card, D. (2001), 'Immigrant Inflows, Native Outflows, and the Local Labor Market Impacts of Higher Immigration', Journal of Labor Economics 19(1), 22-64.

Card, D. (2005), 'Is the New Immigration Really So Bad?', The Economic Journal 115(507), F300-F323. 
Card, D. (2007), How Immigration Affects US Cities, Technical report, CReAM Discussion Paper.

Card, D. and DiNardo, J. (2000), 'Do immigrant inflows lead to native outflows?', American Economic Review 90(2), 360-367.

Challen, S. (2011), 'Measuring immigration policy', PhD Dissertation. Department of Government. Harvard University .

Dustmann, C. and Preston, I. P. (2007), 'Racial and economic factors in attitudes to immigration', The B.E. Journal of Economic Analysis 8 Policy 7(1), Article 62.

Friedberg, R. and Hunt, J. (1995), 'The Impact of Immigrants on Host Country Wages, Employment and Growth', The Journal of Economic Perspectives 9(2), 23-44.

Gaston, N. and Nelson, D. (2000), 'Immigration and labour-market outcomes in the United States: A political-economy puzzle', Oxford Review of Economic Policy 16(3), 104-114.

Hainmueller, J. and Hiscox, M. (2010), 'Attitudes toward highly skilled and low-skilled immigration: Evidence from a survey experiment', American Political Science Review 104(01), 6184.

Jones, R. (1971), 'A Three-Factor Model in Theory, Trade, and History', Trade, Balance of Payments, and Growth pp. 3-21.

Kinder, D. and Sears, D. (1981), 'Prejudice and politics: Symbolic racism versus racial threats to the good life', Journal of Personality and Social Psychology 40, 41431.

Leamer, E. and Levinsohn, J. (1995), International Trade Theory: The Evidence. In Handbook of International Economics, Vol. 3, Amsterdam: North-Holland, chapter International Trade Theory: The Evidence, pp. 1339-1394.

Lewis, E. (2005), Immigration, Skill Mix, and the Choice of Technique, Federal Reserve Bank of Philadelphia, Research Dept.

Longhi, S., Nijkamp, P. and Poot, J. (2005), 'A Meta-Analytic Assessment of the Effect of Immigration on Wages', Journal of Economic Surveys 19(3), 451-477.

Malhotra, N., Margalit, Y. and Mo, C. (2011), 'Economic explanations for opposition to immigration: Distinguishing between prevalence and magnitude', Mimeo, Columbia University

Mayda, A. (2006), 'Who is against immigration? a cross-country investigation of individual attitudes toward immigrants', Review of Economics and Statistics 88(3), 510-530.

Orrenius, P. M. and Zavodny, M. (2007), 'Does immigration affect wages? a look at occupationlevel evidence', Labour Economics 14(5), 757-773. 
Ottaviano, G. and Peri, G. (2006), 'Rethinking the effects of immigration on wages', NBER Working Paper.

Ottaviano, G. and Peri, G. (2008), 'Immigration and National Wages: Clarifying the Theory and the Empirics', NBER WP 14188.

Ottaviano, G. and Peri, G. (2011), 'Rethinking the effects of immigration on wages', Journal of the European Economic Association forthcoming.

Peri, G. and Sparber, C. (2009), 'Task specialization, immigration, and wages', American economic journal. Applied economics 1(3), 135-169.

Razin, A. and Sadka, E. (1995), 'Resisting migration: Wage rigidity and income distribution', American Economic Review 85(2), 312-316.

Scheve, K. and Slaughter, M. (2001), 'Labor market competition and individual preferences over immigration policy', Review of Economics and Statistics 83(1), 133-145.

Sears, D., Lau, R., Tyler, T. and Allen, H. (1980), 'Self interest vs. symbolic politics in policy attitudes and presidential voting', American Political Science Review 74, 67084.

Sniderman, P., Hagendoorn, L. and Prior, M. (2004), 'Predisposing factors and situational triggers: Exclusionary reactions to immigrant minorities', American Political Science Review 98(01), 35-49. 


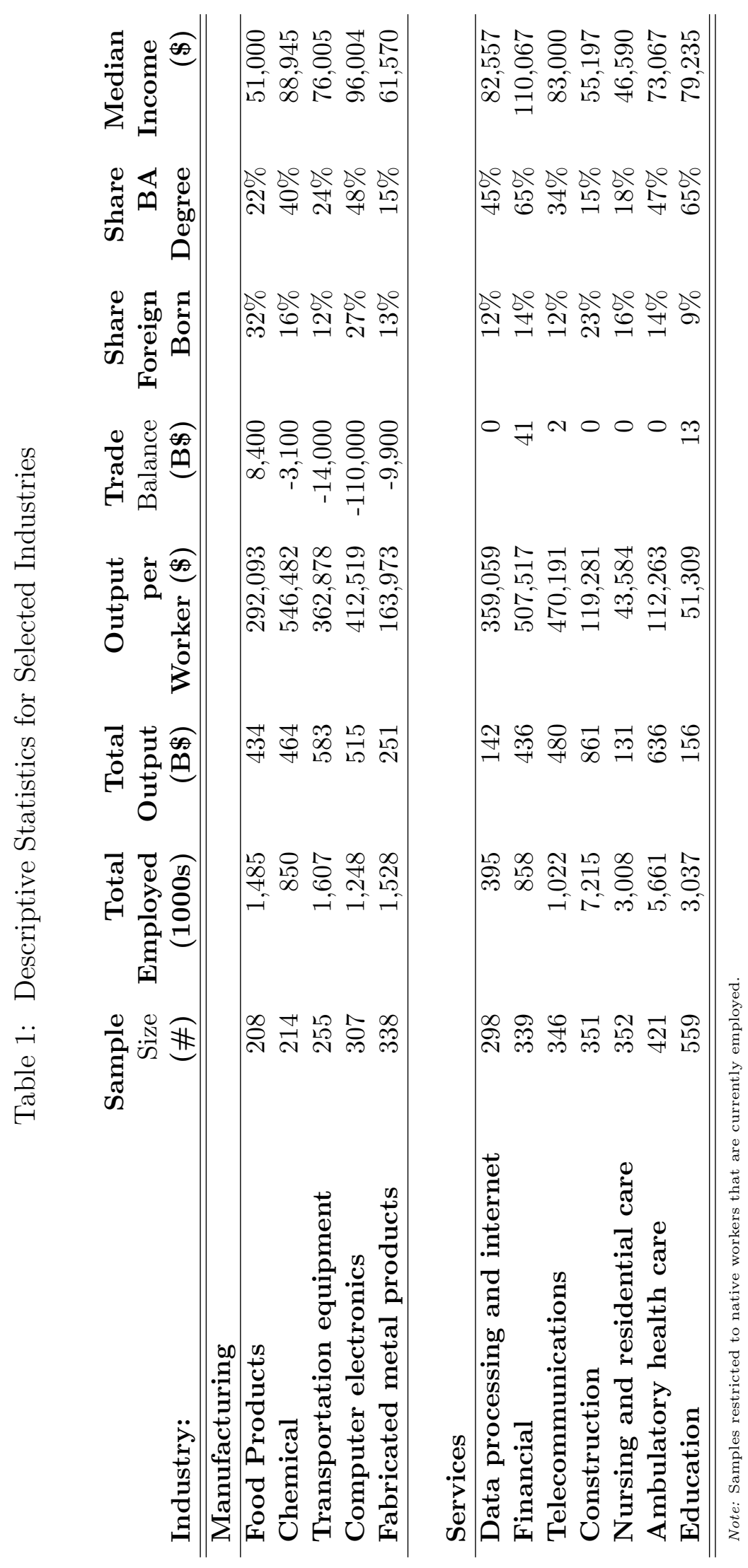


Table 2: Education and Attitudes towards Highly Skilled and Low Skilled Immigration by Industry

\begin{tabular}{lcc} 
& Education Effect on & Attitudes Toward: \\
\hline \multirow{2}{*}{ Industry Sample: } & $\begin{array}{c}\text { Highly Skilled } \\
\text { Immigration }\end{array}$ & $\begin{array}{c}\text { Low Skilled } \\
\text { Immigration }\end{array}$ \\
\hline All Workers & 0.365 & 0.278 \\
Construction & $(0.027)$ & $(0.032)$ \\
Food Manufacturing & 0.274 & 0.393 \\
& $(0.104)$ & $(0.114)$ \\
Chemical Manufacturing & 0.549 & 0.548 \\
& $(0.109)$ & $(0.131)$ \\
Fabricated Metals & 0.832 & 0.751 \\
Computer Electronics & $(0.116)$ & $(0.131)$ \\
Transportation Equipment & 0.441 & 0.290 \\
Telecommunications & $(0.106)$ & $(0.096)$ \\
& 0.223 & 0.432 \\
Internet data processing & $(0.106)$ & $(0.116)$ \\
Financial Sector & 0.487 & 0.286 \\
& $(0.114)$ & $(0.121)$ \\
Educational Services & 0.326 & 0.099 \\
Ambulatory Healthcare & $(0.101)$ & $(0.111)$ \\
Nursing & -0.008 & -0.067 \\
& $(0.101)$ & $(0.109)$ \\
& 0.138 & 0.171 \\
& $(0.101)$ & $(0.116)$ \\
& 0.434 & 0.253 \\
& $(0.071)$ & $0.079)$ \\
& 0.491 & $(0.101)$ \\
\hline
\end{tabular}

Note: Probit coefficients show with standard errors (clustered by respondent) in parenthesis. Each cell provides the estimate of the education coefficient obtained from separate regressions of attitudes towards either highly skilled or low skilled immigration on native education and the full set of baseline covariates (estimates not shown) for different subsamples of workers that are currently employed in the different industries. 
Table 3: Attitudes towards Highly Skilled and Low Skilled Immigration by Industry

\begin{tabular}{|c|c|c|c|c|c|c|}
\hline Model & (1) & (2) & (3) & (4) & (5) & (6) \\
\hline Worker Sample: & \multicolumn{2}{|c|}{ All Workers } & \multicolumn{2}{|c|}{ Highly Skilled } & \multicolumn{2}{|c|}{ Low Skilled } \\
\hline \multirow{2}{*}{$\begin{array}{l}\text { Attitudes Towards Type of } \\
\text { Immigration: }\end{array}$} & Highly & Low & Highly & Low & Highly & Low \\
\hline & Skilled & Skilled & Skilled & Skilled & Skilled & Skilled \\
\hline \multirow{2}{*}{ Construction } & 0.124 & -0.152 & 0.105 & -0.198 & 0.122 & -0.192 \\
\hline & $(0.159)$ & $(0.143)$ & $(0.242)$ & $(0.203)$ & $(0.194)$ & $(0.175)$ \\
\hline \multirow[t]{2}{*}{ Food Manufacturing } & 0.086 & 0.0131 & 0.403 & 0.342 & -0.0604 & -0.117 \\
\hline & $(0.160)$ & $(0.147)$ & $(0.258)$ & $(0.208)$ & $(0.205)$ & $(0.188)$ \\
\hline \multirow[t]{2}{*}{ Chemical Manufacturing } & 0.164 & -0.0363 & 0.403 & 0.298 & -0.118 & -0.308 \\
\hline & $(0.170)$ & $(0.156)$ & $(0.242)$ & $(0.208)$ & $(0.239)$ & $(0.230)$ \\
\hline \multirow[t]{2}{*}{ Fabricated Metals } & 0.155 & -0.035 & 0.24 & 0.118 & 0.135 & -0.091 \\
\hline & $(0.157)$ & $(0.138)$ & $(0.230)$ & $(0.193)$ & $(0.194)$ & $(0.169)$ \\
\hline \multirow[t]{2}{*}{ Computer Electronics } & 0.295 & 0.125 & 0.464 & 0.205 & 0.118 & 0.168 \\
\hline & $(0.152)$ & $(0.137)$ & $(0.212)$ & $(0.181)$ & $(0.222)$ & $(0.187)$ \\
\hline \multirow[t]{2}{*}{ Transportation Equipment } & -0.18 & -0.151 & -0.072 & 0.3 & -0.248 & -0.354 \\
\hline & $(0.185)$ & $(0.146)$ & $(0.247)$ & $(0.197)$ & $(0.247)$ & $(0.197)$ \\
\hline \multirow[t]{2}{*}{ Telecommunications } & 0.265 & -0.024 & 0.239 & 0.130 & 0.273 & -0.096 \\
\hline & $(0.151)$ & $(0.135)$ & $(0.221)$ & $(0.189)$ & $(0.197)$ & $(0.172)$ \\
\hline \multirow[t]{2}{*}{ Internet data processing } & 0.698 & 0.408 & 0.481 & 0.305 & 0.904 & 0.583 \\
\hline & $(0.156$ & $(0.146)$ & $(0.206)$ & $(0.177)$ & $(0.213)$ & $(0.197)$ \\
\hline \multirow[t]{2}{*}{ Financial Sector } & 0.394 & 0.319 & 0.409 & 0.444 & 0.476 & 0.373 \\
\hline & $(0.146)$ & $(0.130)$ & $(0.194)$ & $(0.164)$ & $(0.231)$ & $(0.198)$ \\
\hline \multirow[t]{2}{*}{ Educational Services } & 0.361 & 0.127 & 0.401 & 0.317 & 0.278 & -0.056 \\
\hline & $(0.134)$ & $(0.116)$ & $(0.184)$ & $(0.153)$ & $(0.198)$ & $(0.173)$ \\
\hline \multirow[t]{2}{*}{ Ambulatory Healthcare } & 0.288 & 0.02 & 0.307 & 0.156 & 0.318 & -0.033 \\
\hline & $(0.147)$ & $(0.130)$ & $(0.200)$ & $(0.167)$ & $(0.207)$ & $(0.183)$ \\
\hline Observations & 8,142 & 8,142 & 4,092 & 4,092 & 4,050 & 4050 \\
\hline
\end{tabular}

Note: Probit coefficients show with standard errors (clustered by respondent) in parenthesis. Each column presents a separate regression of attitudes towards either highly skilled or low skilled immigration on a set of industry dummies (the reference category is nursing) and the full set of baseline covariates (estimates not shown). Columns 1 and 2 refer to the sample of all native workers. Columns $2 \& 3$ only include highly skilled native workers (defined as those with at least some college education). Columns 5 \& 6 only include low skilled native workers (defined as those without any college education). 


\section{Figures}

Figure 1: Selection of Target Industries Based on Exposure to Immigration
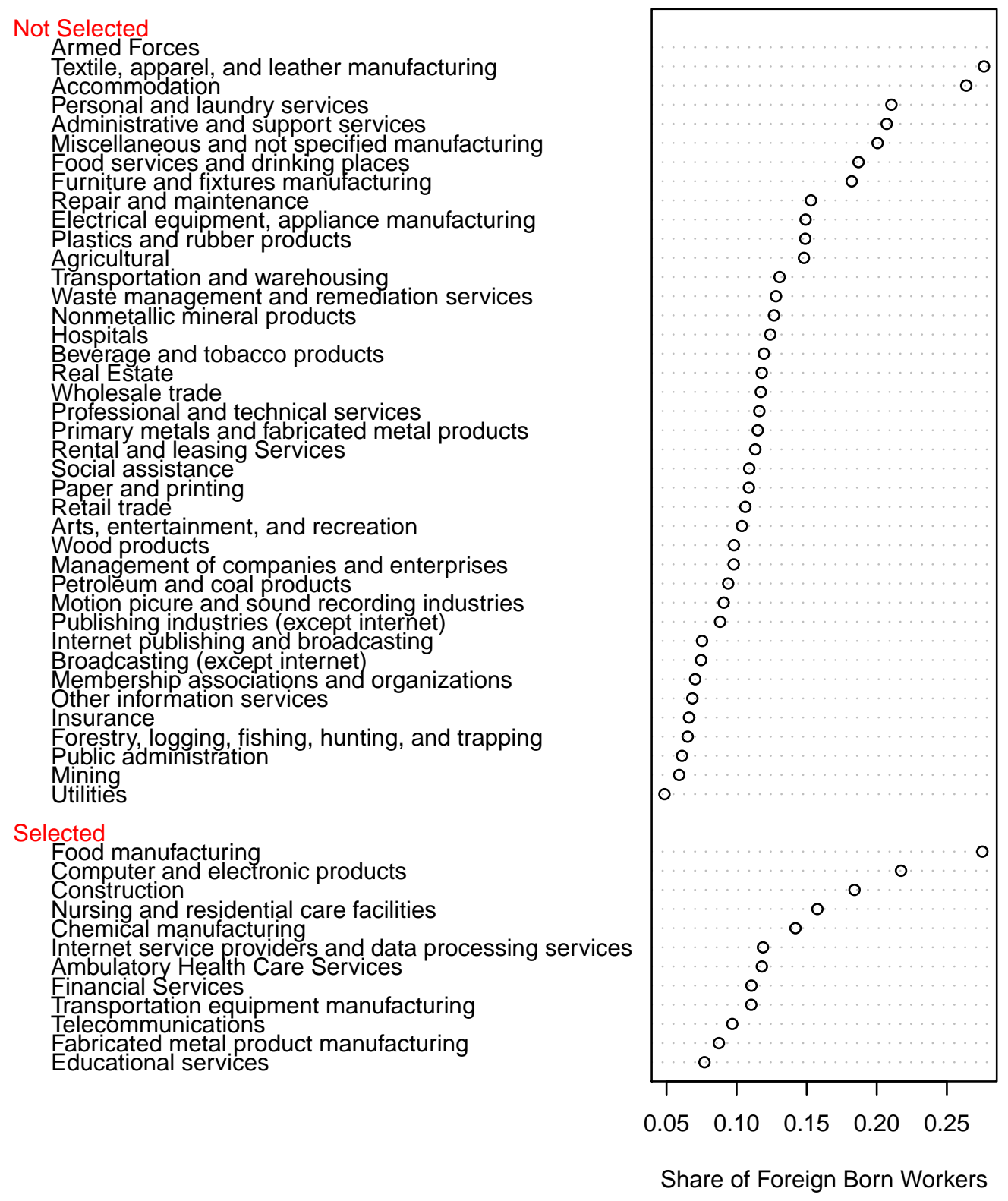

Note: Share of Foreign Born Workers is measured in 2009 (Source: March Supplement of the Current Population Survey). 
Figure 2: Selection of Target Industries Based on Exposure to Immigration

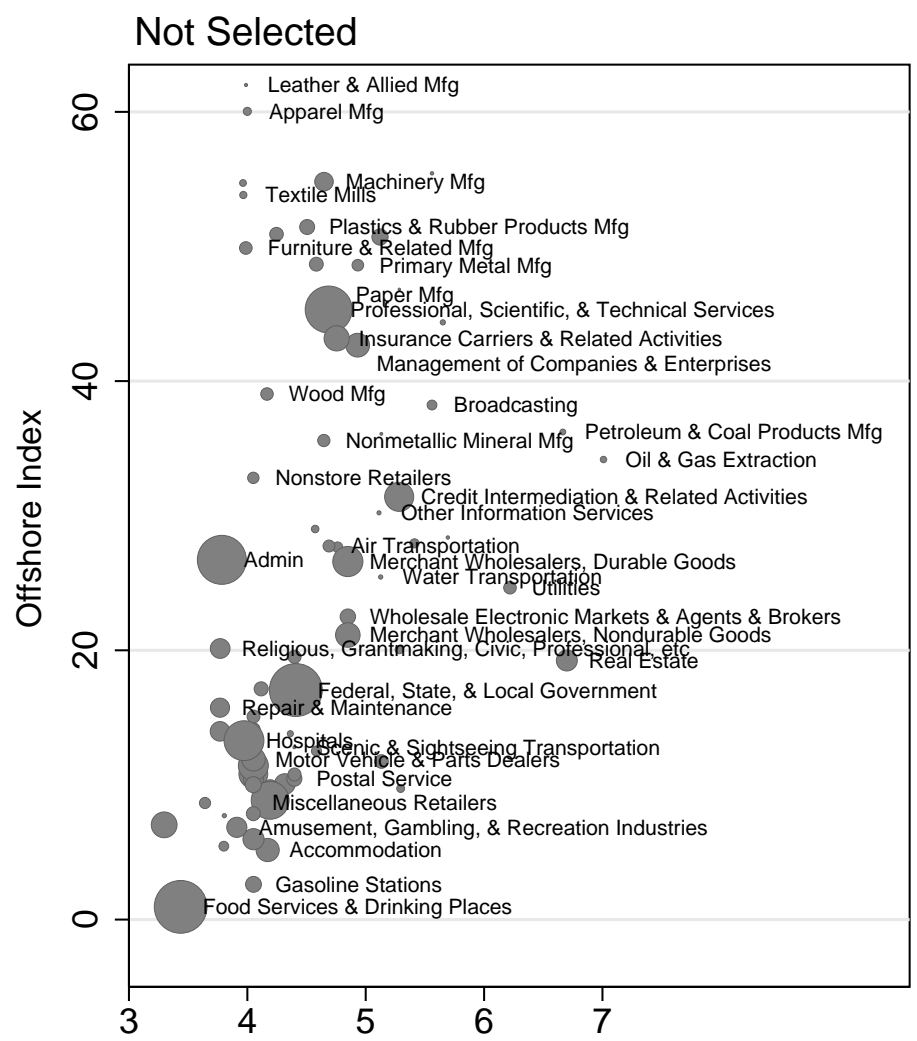

Selected

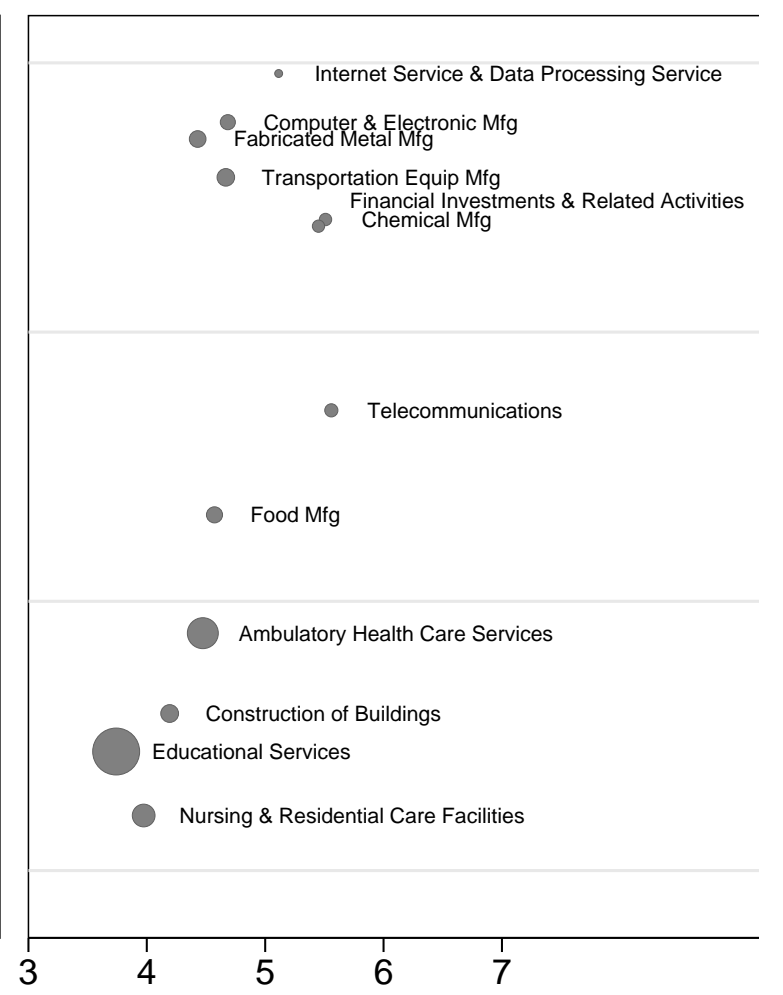

Value Added per Worker

Note: Share of Foreign Born Workers is measured in 2009 (Source: March Supplement of the Current Population Survey). 
Figure 3: Educational attainment of natives and support for immigration of high and low skilled workers

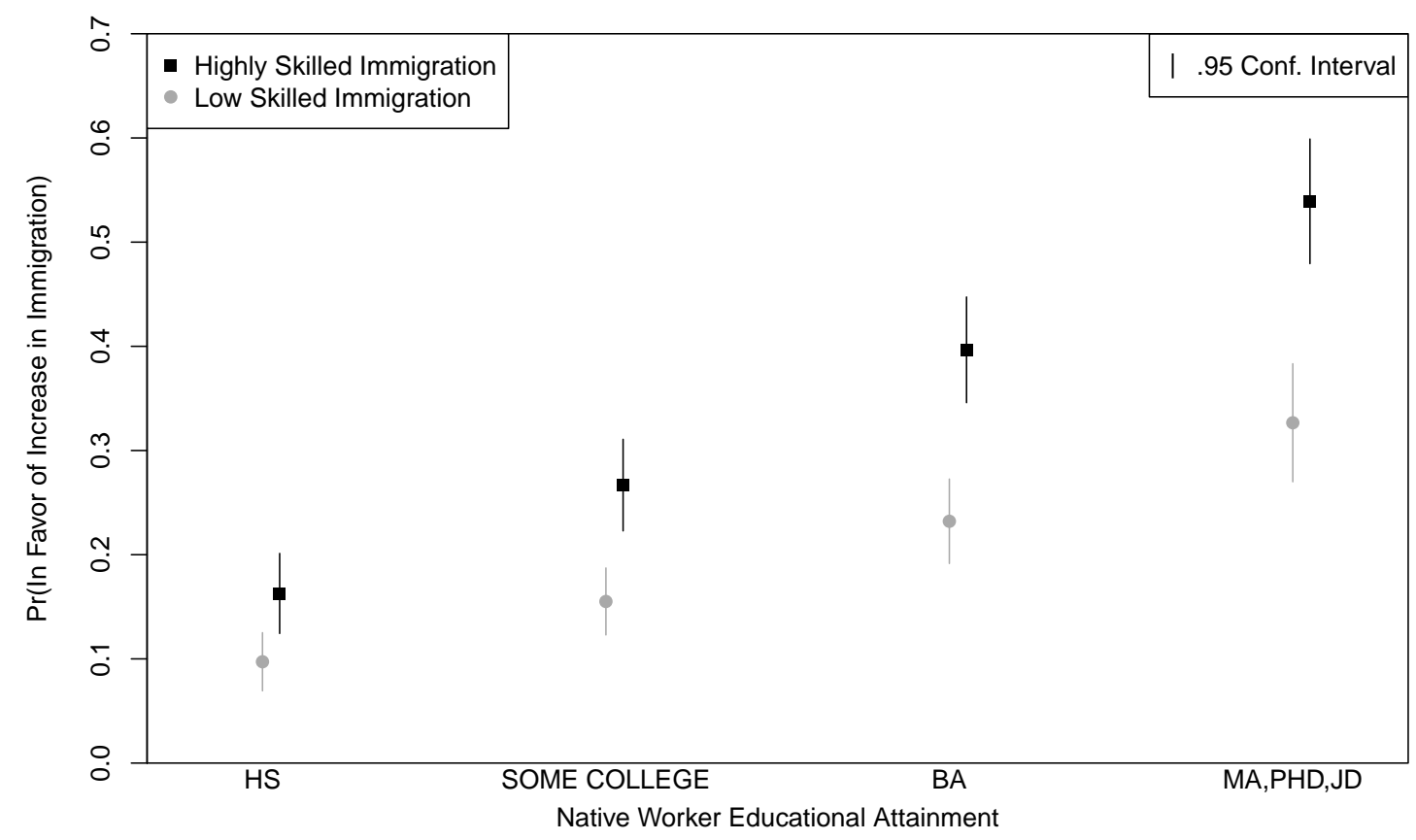

Note: Results are based on the regression coefficients reported in Table 2 The estimates hold all variables but education at the respective medians. 
Figure 4: Marginal effect of college degree, by industry

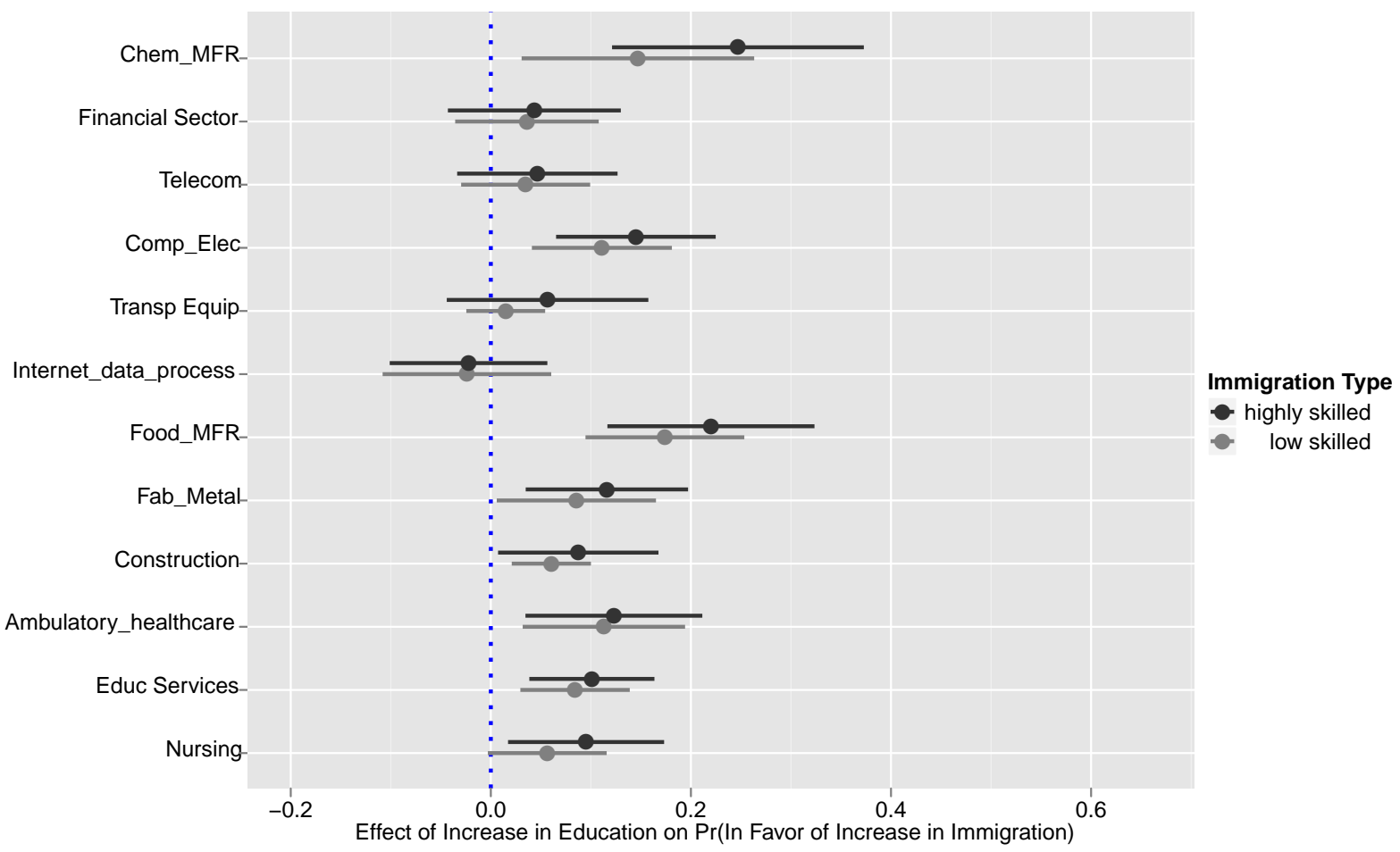

Note: See Table 2 for a description of the regressions used to generate theses estimates. Industries along the vertical axis are sorted by the skill intensity of the industry (as measured by the value added per worker). 
Figure 5: Support for immigration, by industry share of foreign born workers

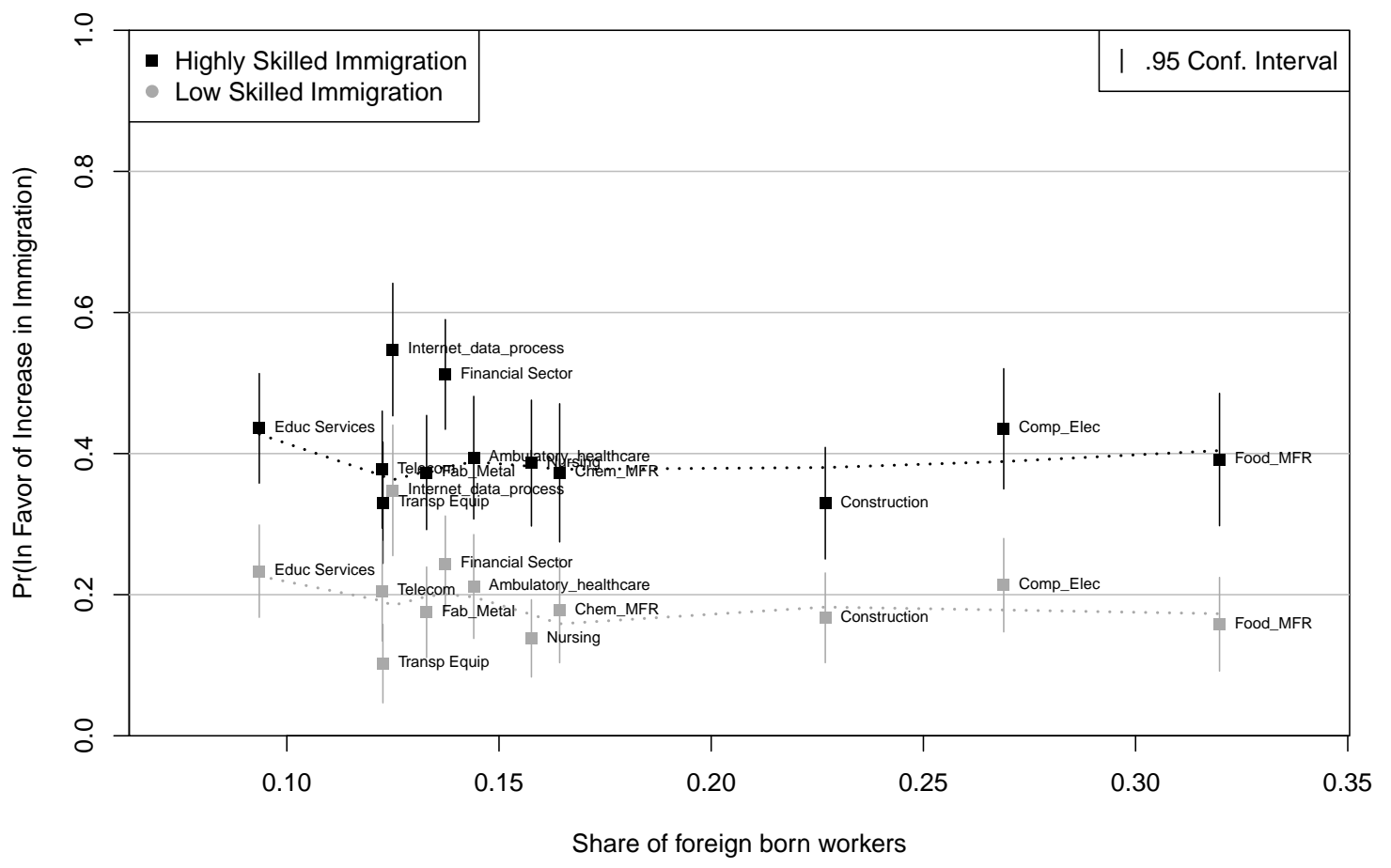

Note: See Table 3 for a description of the regressions used to generate these estimates. 
Figure 6: Support for immigration, by industry relative skill ratio

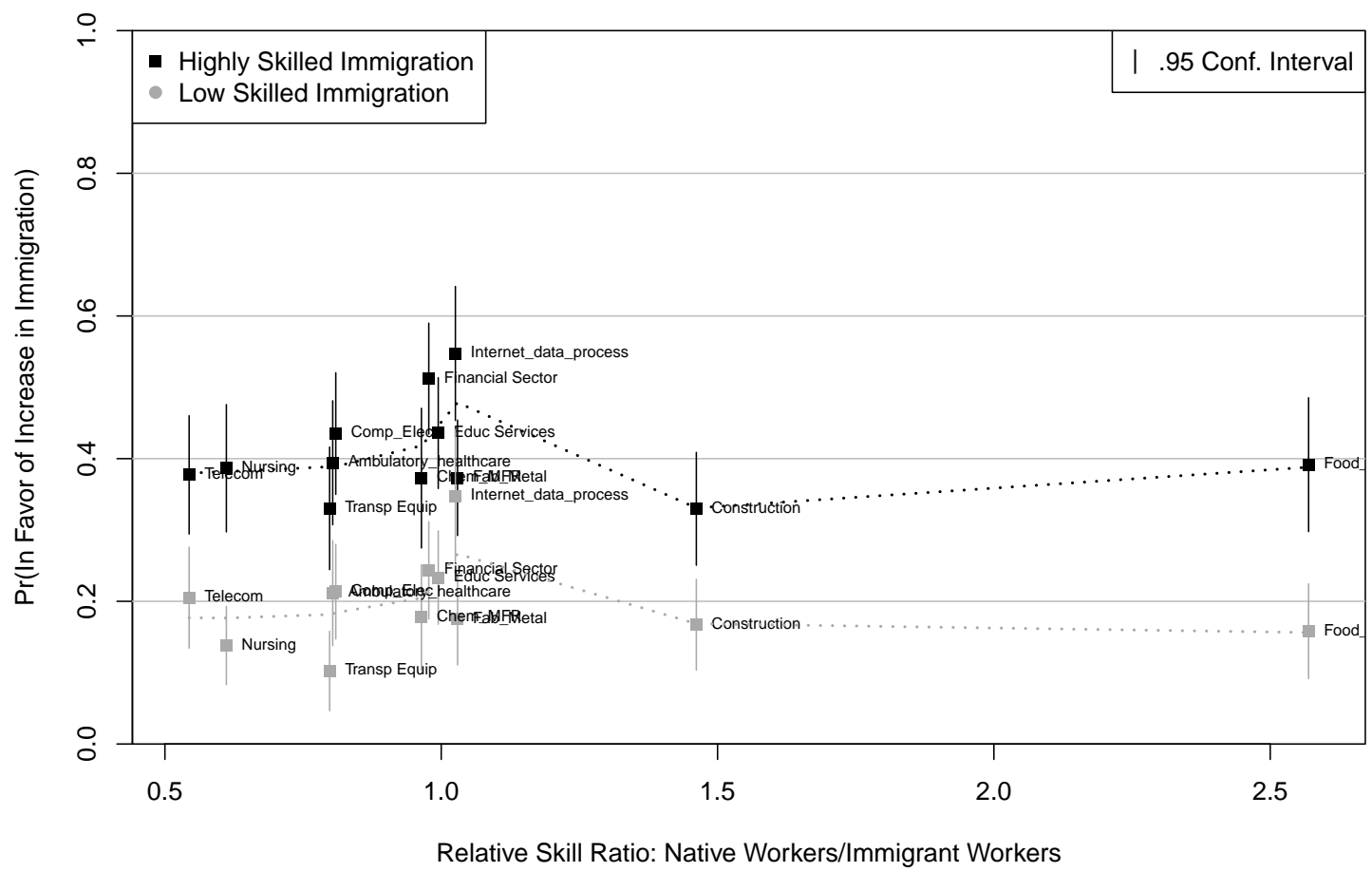

Note: See Table 3 for a description of the regressions used to generate these estimates. 
Figure 7: Support for immigration, by industry relative skill ratio

Highly Skilled Workers

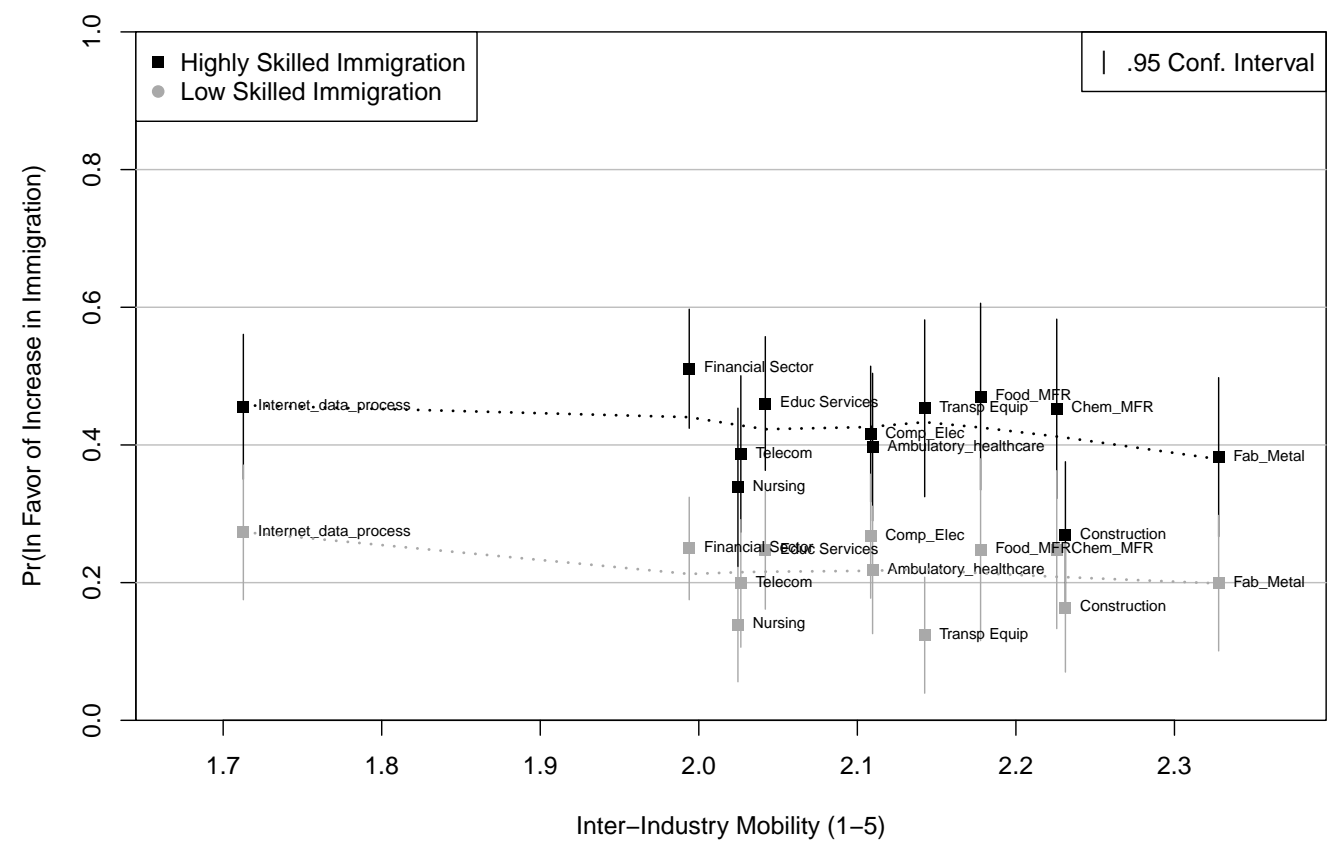

Low Skilled Workers

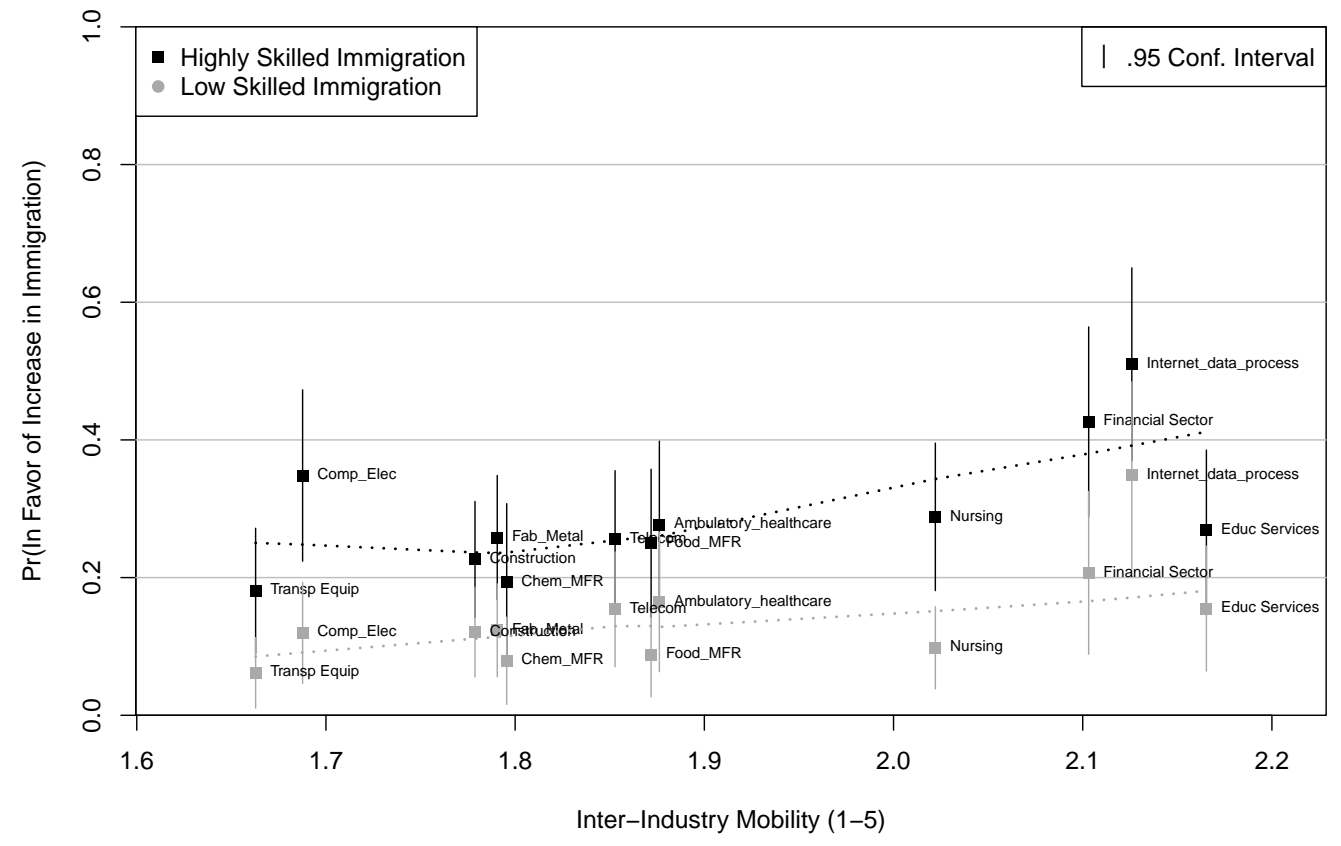

Note: See Table 3 for a description of the regressions used to generate these estimates. 
Figure 8: Skill level and request of action to express opposition to immigration

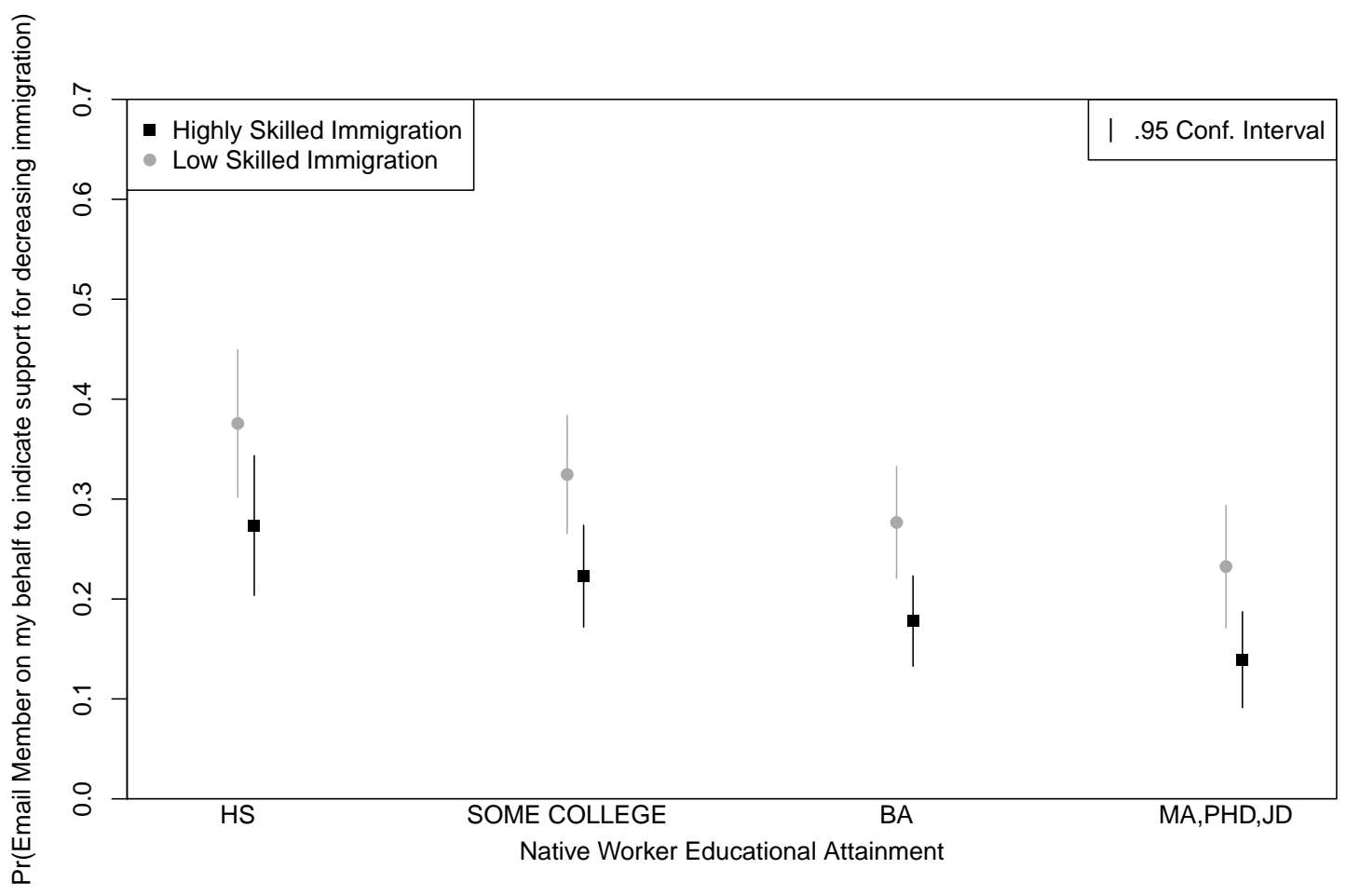

Note: The dependent variable in this analysis is coded as 1 if the respondent says $\mathrm{s} /$ he wants the email sent to indicate support for decreasing immigration and zero otherwise 


\section{APPENDIX}

Table A.1: Interaction: Education and Immigration Attitudes

\begin{tabular}{lc}
\hline \hline Sample & All Workers \\
\hline Education & 0.253 \\
& $(0.030)$ \\
Education * Highly Skilled Immigration & 0.0975 \\
& $(0.020)$ \\
Highly Skilled Immigration & 0.182 \\
& $(0.066)$ \\
\hline Observations & 17,248 \\
\hline \hline
\end{tabular}

Note: Probit coefficients show with standard errors (clustered by respondent) in parenthesis. The dependent variable is a binary indicator that is coded as a 1 of workers that are in favor of an increasing immigration and zero otherwise. The independent variables include workers' education level (measured on a four point scale from less than high school to graduate education), an indicator for the skill frame of the immigration question ( 1 if highly skilled and 0 for low skilled immigration), the interaction between the education and the skill frame, and our full set of baseline covariates (gender, age, race, marital status, income, union membership, and region). 
Figure A.1: Replication of Figure 7a \& 7b with intra industry mobility.

\section{Highly Skilled Workers}

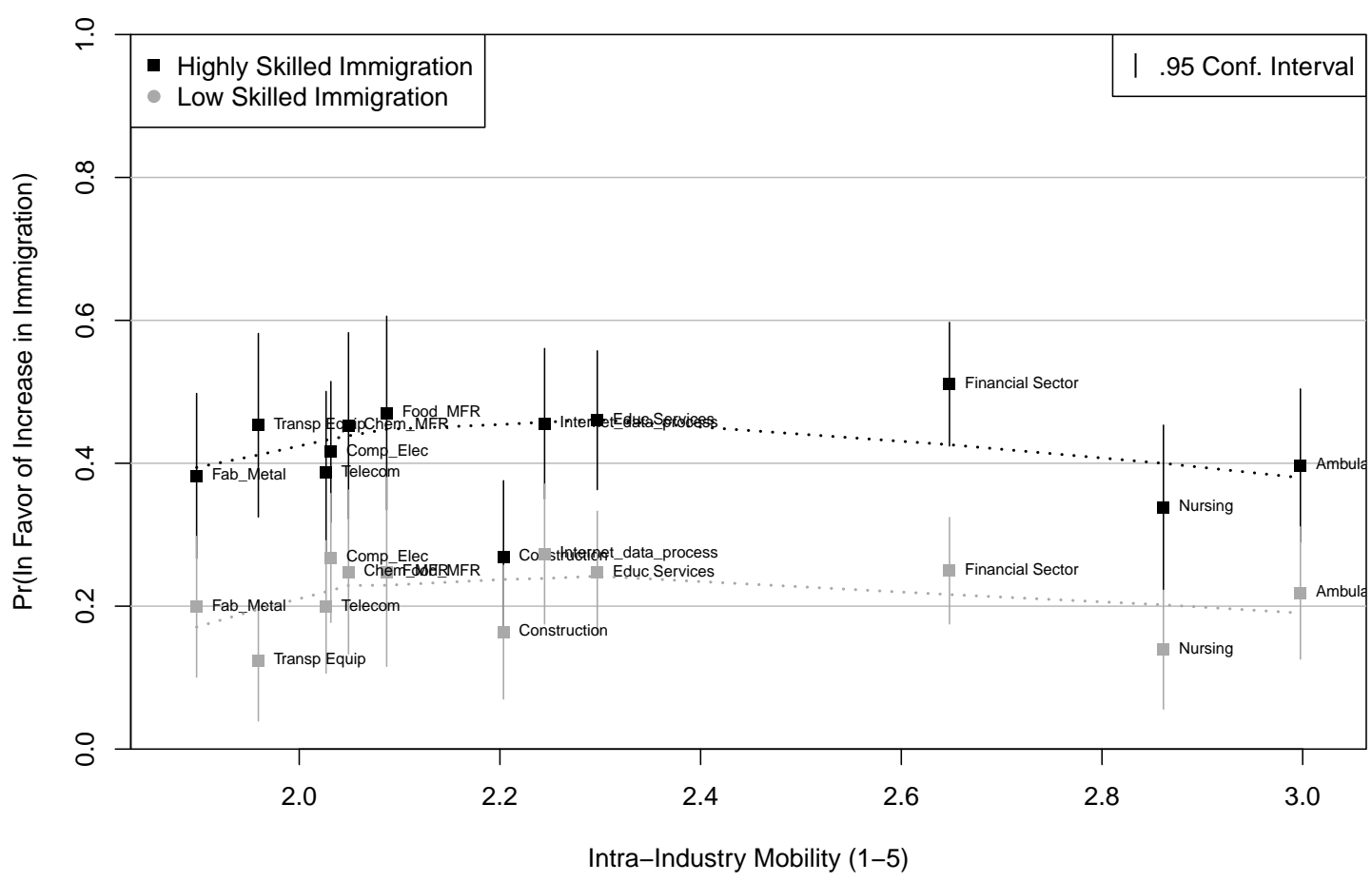

Low Skilled Workers

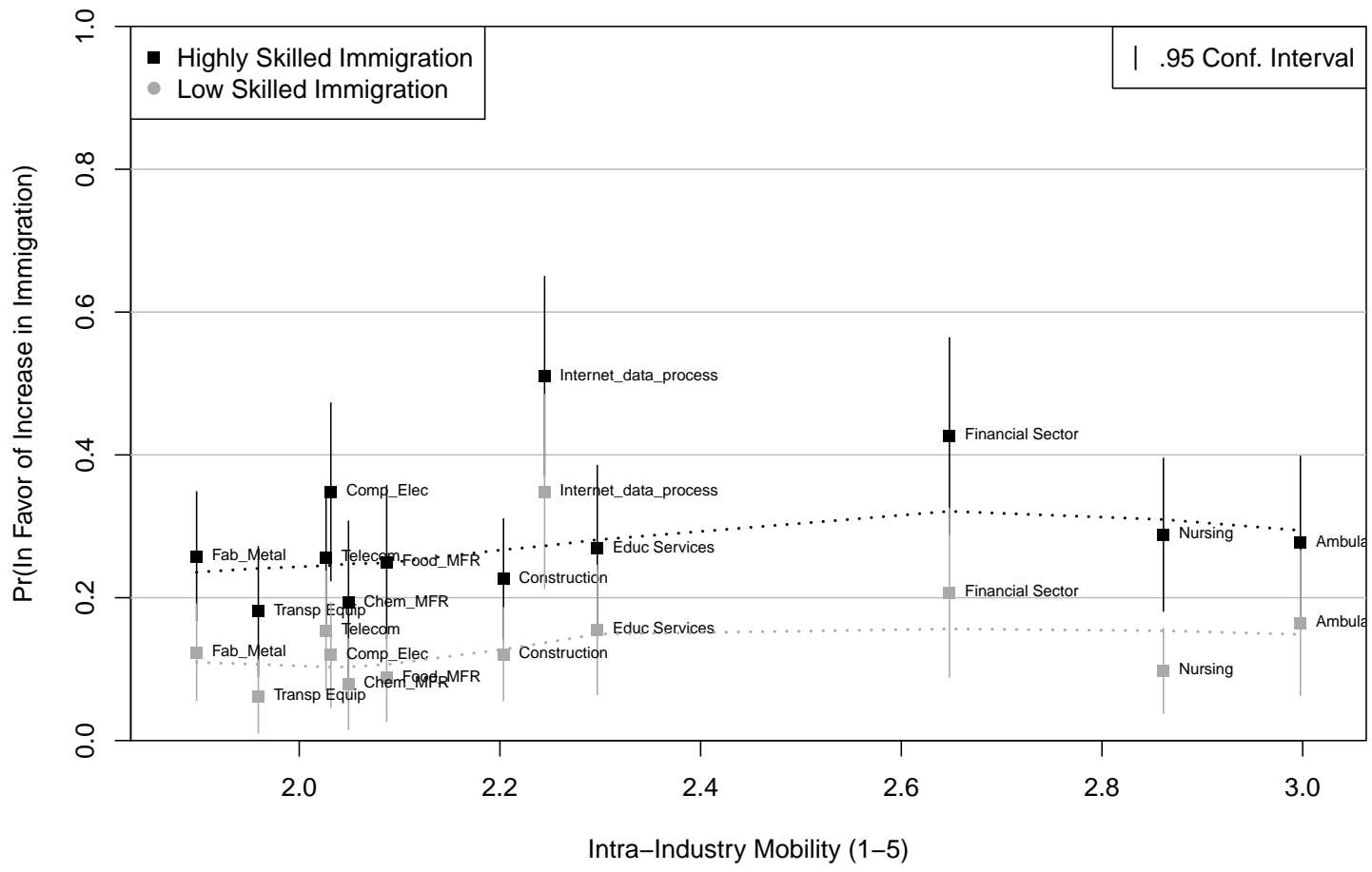


Figure A.2: Replication of Figure 4 with Behavioral Measure (request of action to express opposition to immigration).

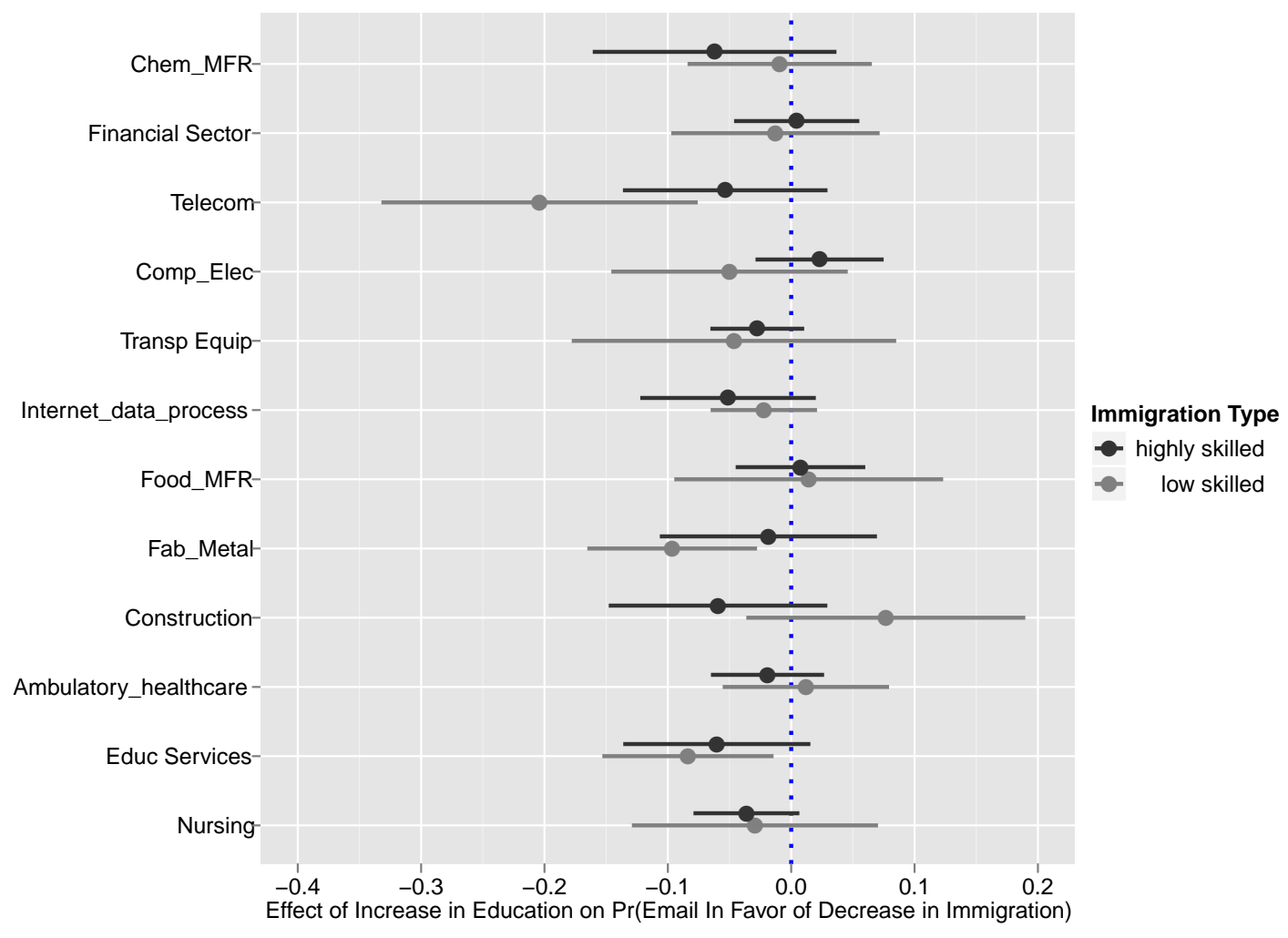


Figure A.3: Replication of Figure 5 with Behavioral Measure (request of action to express opposition to immigration).

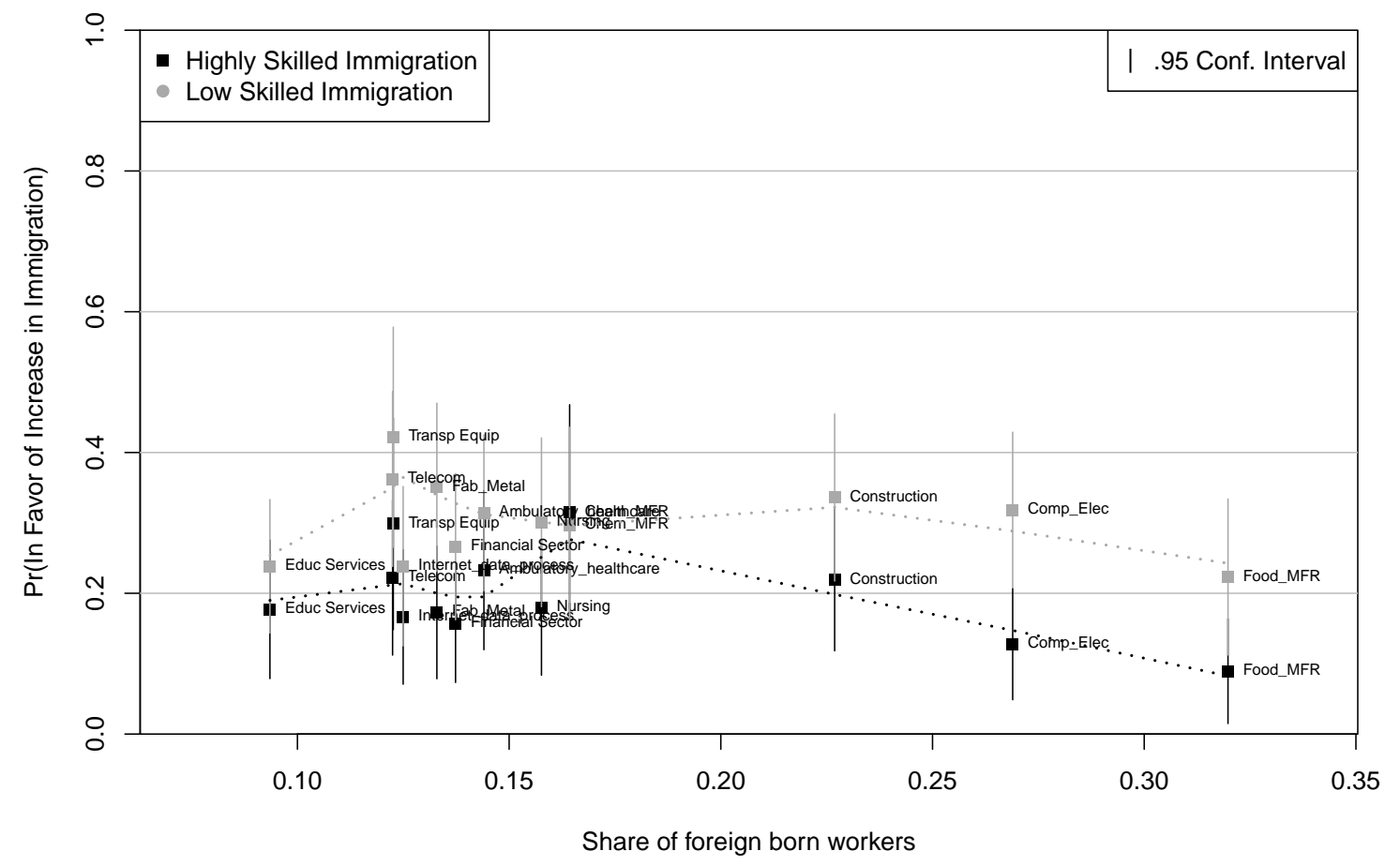


Figure A.4: Replication of Figure 6 with Behavioral Measure (request of action to express opposition to immigration).

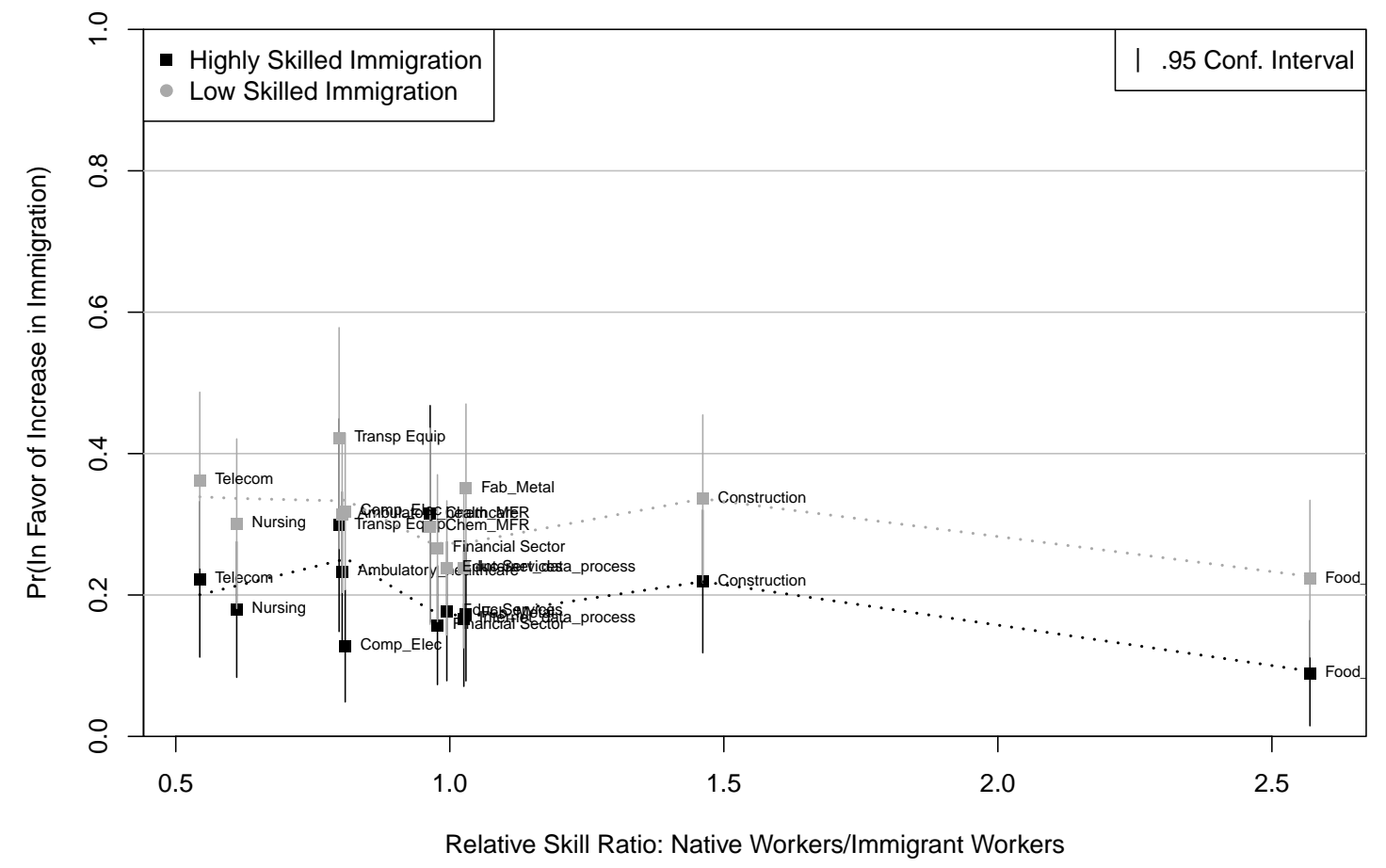


Figure A.5: Replication of Figure $7 \mathrm{a}$ and $7 \mathrm{~b}$ with Behavioral Measure (request of action to express opposition to immigration).

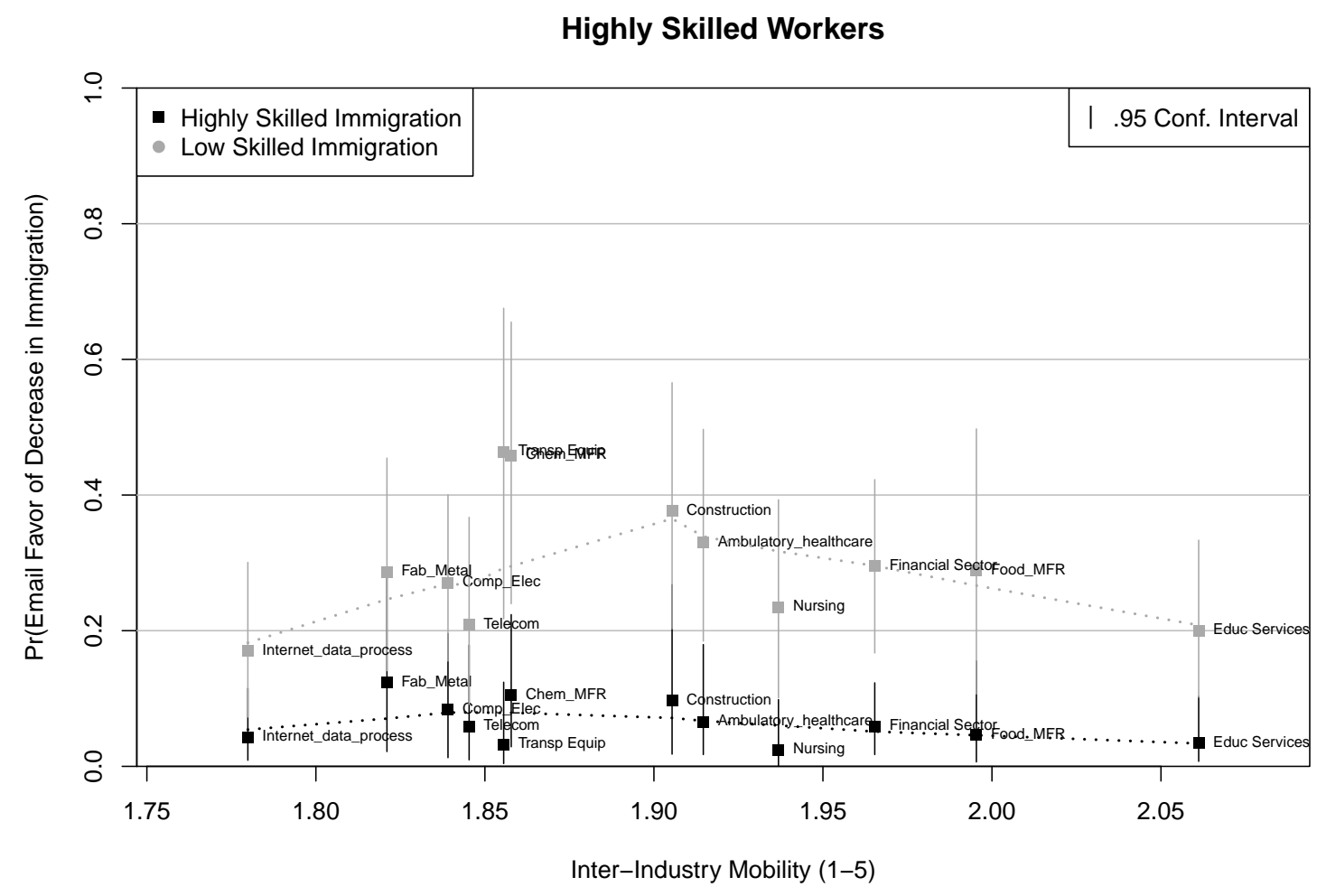

Low Skilled Workers

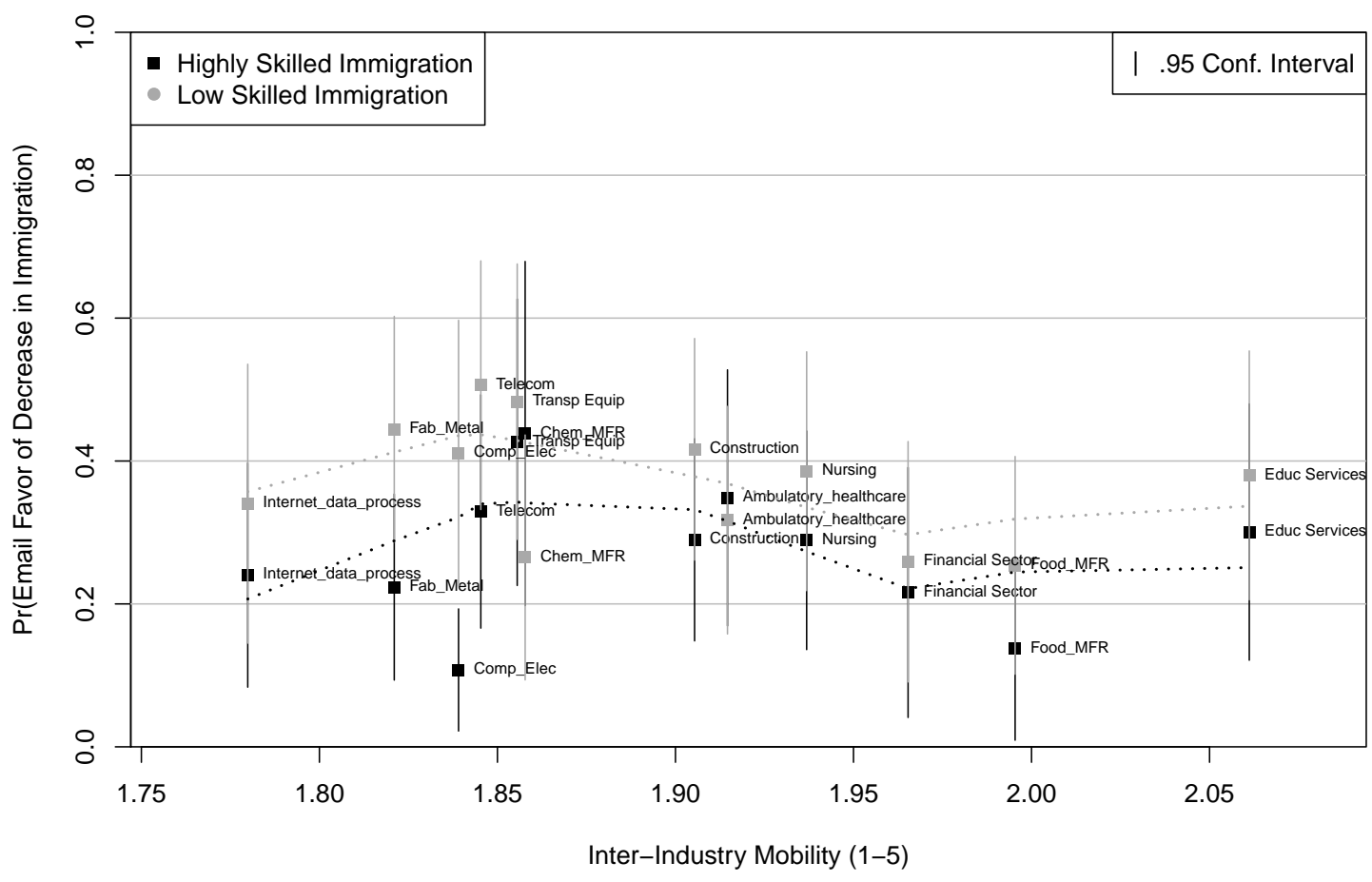

